\title{
Novel magnetic fibrin hydrogel scaffolds containing thrombin and growth factors conjugated iron oxide nanoparticles for tissue engineering
}

\author{
This article was published in the following Dove Press journal: \\ International Journal of Nanomedicine \\ 5 March 2012 \\ Number of times this article has been viewed
}

\author{
Ofra Ziv-Polat \\ Hadas Skaat' \\ Abraham Shahar ${ }^{2}$ \\ Shlomo Margel' \\ 'Department of Chemistry, Bar-llan \\ Institute of Nanotechnology and \\ Advanced Materials, Ramat-Gan \\ 52900, Israel; ${ }^{2}$ NVR Research Ltd, \\ Nes-Ziona 7403I, Israel
}

\begin{abstract}
Novel tissue-engineered magnetic fibrin hydrogel scaffolds were prepared by the interaction of thrombin-conjugated iron oxide magnetic nanoparticles with fibrinogen. In addition, stabilization of basal fibroblast growth factor (bFGF) was achieved by the covalent and physical conjugation of the growth factor to the magnetic nanoparticles. Adult nasal olfactory mucosa (NOM) cells were seeded in the transparent fibrin scaffolds in the absence or presence of the free or conjugated bFGF-iron oxide nanoparticles. The conjugated bFGF enhanced significantly the growth and differentiation of the NOM cells in the fibrin scaffolds, compared to the same or even five times higher concentration of the free bFGF. In the presence of the bFGFconjugated magnetic nanoparticles, the cultured NOM cells proliferated and formed a threedimensional interconnected network composed mainly of tapered bipolar cells. The magnetic properties of these matrices are due to the integration of the thrombin- and bFGF-conjugated magnetic nanoparticles within the scaffolds. The magnetic properties of these scaffolds may be used in future work for various applications, such as magnetic resonance visualization of the scaffolds after implantation and reloading the scaffolds via magnetic forces with bioactive agents, eg, growth factors bound to the iron oxide magnetic nanoparticles.
\end{abstract}

Keywords: thrombin, fibroblast growth factor, fibrin scaffold, iron oxide nanoparticles, tissue engineering, magnetism, bioactive nanoparticle

\section{Introduction}

Fibrin hydrogels are common materials being explored as matrices for tissue engineering applications, eg, tissue engineering of adipose, cardiovascular, ocular, muscle, liver, skin, cartilage, bone and neuronal tissues. ${ }^{1-4}$ The fibrin hydrogels combine some important advantages such as inherent flexibility, soft, high seeding efficiency, and uniform cell distribution. In addition, they cast easily into different three-dimensional (3D) shapes and can be injected directly into the site of an injury for in situ gelation. Furthermore, fibrin contains cell-binding sites and thus enhances cell adhesion. ${ }^{5,6}$ Fibrin hydrogels are natural polymers made by mixing two blood coagulation components, fibrinogen and thrombin, which form a clot upon mixing. In human plasma, the half-life of thrombin is shorter than 15 seconds due to tight control by protease inhibitors and components of the vessel's wall. ${ }^{7}$ In previous studies, we have demonstrated that appropriate conjugation of thrombin to iron oxide $\left(\gamma-\mathrm{Fe}_{2} \mathrm{O}_{3}\right)$ magnetic nanoparticles preserved the thrombin-clotting activity, stabilized the thrombin against its major inhibitor, antithrombin III, and improved its storage stability. ${ }^{8,9}$
Department of Chemistry, The Institute of Nanotechnology and Advanced Materials, Bar-Ilan University, Ramat-Gan 52900, Israel Tel +97235318 86I

Fax +97236355208

Email shlomo.margel@mail.biu.ac.il 
In the present study, these thrombin-conjugated $\gamma-\mathrm{Fe}_{2} \mathrm{O}_{3}$ nanoparticles were used to fabricate novel magnetic fibrin hydrogel scaffolds.

Iron oxide nanoparticles are of great interest due to their magnetic properties, high surface area-to-volume ratio, biocompatibility, relative nontoxicity, and biodegradability. The use of iron oxide magnetic nanoparticles for various biomedical applications, eg, hyperthermia, diagnostics, cell labeling and sorting, DNA separation, magnetic resonance imaging (MRI) and X-ray contrast agents, magnetic stimulisensitive polymeric systems, and gene and drug delivery, have already been demonstrated. ${ }^{10-18}$ Recent studies in the tissue-engineering field proposed to produce magnetic scaffolds by integration of nonmodified iron oxide nanoparticles in scaffolds made of various materials. For example, Bock et $\mathrm{al}^{19}$ succeeded in transforming standard commercial scaffolds, made of hydroxyapatite-collagen and pure collagen, to magnetic scaffolds by dip-coating the scaffolds in aqueous ferrofluids containing iron oxide nanoparticles. $\mathrm{Hu}$ et $\mathrm{al}^{20}$ and Sivudu et $\mathrm{al}^{21}$ fabricated magnetic hydrogel scaffolds by in situ development of iron oxide nanoparticles in gelatin or polyacrylamide hydrogels, respectively. It has been suggested to use the magnetic properties of these scaffolds for monitoring the scaffolds after implantation by MRI or $\mathrm{X}$-ray, and for reloading the scaffolds after implantation with bioactive agents, such as growth factors, stem cells, or other bioactive reagents that can be bound to magnetic iron oxide nanoparticles. ${ }^{17,19,22,23}$

In order to enhance cell regeneration, scaffolds are often designed as platforms for the delivery of bioactive molecules such as growth factors, angiogenic factors, and differentiation factors. ${ }^{1,2,24,25}$ For example, basal fibroblast growth factor (bFGF, also known as FGF-2) is a mitogenic polypeptide which induces cell divisions in a variety of cell types including skin, blood vessel, muscle, adipose, cartilage, and bone tissues. ${ }^{26,27}$ It also promotes cell proliferation and differentiation in cultures of mouse and human olfactory epithelium. ${ }^{28,29}$ In addition, bFGF has been shown to promote neuron survival, nerve fiber outgrowth, and proliferation of neuronal precursor cells in cultures. ${ }^{26,27,30,31}$ The main disadvantage of free bFGF is its short in vivo half-life of about 3-10 minutes due to rapid enzymatic degradation, which leads to loss of biological activity and functions. ${ }^{26,32}$ To achieve a satisfactory performance, growth factors were adsorbed onto, or encapsulated within, nanomaterials to protect their stability and biological activity. ${ }^{31-33}$

A wide range of cell types have been investigated for tissue-engineering applications. For example, adult nasal olfactory mucosa (NOM) cells are primary cells of interest for implantation into spinal cord injuries. , $^{3,34-39}$ NOM cells are often derived through a simple nasal biopsy from the patient prior to implantation in his or her own body, which eliminates rejection. The NOM is a heterogeneous complex of cells which includes, among others, neuronal progenitor cells (adult stem cells), and glial olfactory ensheathing cells (OECs). ${ }^{35}$ NOM cells have been investigated extensively to see if they have the same capacity to promote neuronal regeneration following spinal cord injuries. ${ }^{34}$ Some of these studies showed that the transplantation of OECs could promote axonal regeneration and functional recovery through their specific glia properties, namely, by secretion of neurotrophic factors (such as nerve growth factor [NGF], brain-derived neurotrophic factors [BDNF] and glial cell-derived neurotrophic factor [GDNF]) and extracellular matrix molecules (such as N-CAM and laminin).,34,36,37 Recent studies indicate that the transplantation of a "pure" OEC population is insufficient for attaining complete recovery of spinal cord injuries. A better recovery of these injuries can be attained using a complex of NOM cells, including, apart from the OECs, neuronal progenitor cells from the neuroepithelium..$^{35,37}$

We describe herein the development of new magnetic fibrin hydrogel scaffolds intended for the cultivation and implantation of NOM cells into spinal cord injuries. The scaffolds are obtained by the interaction of thrombin-conjugated $\gamma-\mathrm{Fe}_{2} \mathrm{O}_{3}$ magnetic nanoparticles and fibrinogen. In addition, we describe a new method for stabilization of bFGF by covalent or physical conjugation to $\gamma-\mathrm{Fe}_{2} \mathrm{O}_{3}$ nanoparticles. Adult NOM cells were seeded in the magnetic fibrin scaffolds in the absence or presence of the free or conjugated bFGF-iron oxide nanoparticles. The aim of this study was to characterize these novel scaffolds, and to examine the influence of the bFGF-conjugated nanoparticles on the growth of NOM cells seeded in these scaffolds, as compared with the free factor.

\section{Materials and methods Materials}

The following analytical-grade chemicals were purchased from commercial sources and used without further purification: ferric chloride hexahydrate, hydrochloric acid (1 M), sodium hydroxide ( $1 \mathrm{M})$, sodium nitrite, glutaraldehyde, paraformaldehyde (4\%), Triton X-100, gelatin from porcine skin, human serum albumin (HSA), bovine serum albumin (BSA), rhodamine B isothiocyanate 
(RITC), divinyl sulfone (DVS), triethylamine (TEA), bovine fibrinogen, bovine fibronectin, aprotinin, D-glucose and poly-L-lysine (PLL; MW 30,000-70,000) from Sigma (Israel); recombinant human bFGF from PeproTech (Israel); bovine thrombin and factor XIII from Merck (Israel); Midi-MACS magnetic columns from Miltenyi Biotec GmbH (Germany); bicarbonate buffer (BB; 0.1 $\mathrm{M}, \mathrm{pH}$ 8.4), phosphate-buffered saline (PBS free of $\mathrm{Ca}^{+2}$ and $\mathrm{Mg}^{+2}$; $0.1 \mathrm{M}, \mathrm{pH}$ 7.4), Dulbecco's modified Eagle's medium-nutrient mixture F-12 (DMEM-F12), fetal calf serum (FCS), gentamicin, glutamine, Hepes, and trypsin-EDTA solution (0.25\%) from Biological-Industries (Israel); Bio-Rad protein assay kit (Bradford) from BioRad (Germany); tissue culture plates (24 wells) and $35 \mathrm{~cm}$ culture plates from JET BioFiL (Israel); chitosan microcarriers (MCs) from Medovent $\mathrm{GmbH}$ (Germany). Water was purified by passing deionized water through an Elgastat Spectrum reverse osmosis system (Elga, High Wycombe, UK).

\section{Synthesis of $\gamma-\mathrm{Fe}_{2} \mathrm{O}_{3}$ nanoparticles}

Iron oxide nanoparticles of $19.8 \pm 4.7 \mathrm{~nm}$ diameter were prepared via nucleation and growth mechanism, as described previously. ${ }^{10,40}$ Briefly, $240 \mathrm{mg}$ of gelatin were dissolved in $80 \mathrm{~mL}$ of water at $60^{\circ} \mathrm{C}$. Then, $160 \mu \mathrm{L}$ of a $\mathrm{Fe}^{+2}$ solution $(10 \mathrm{mmol}$ in $5 \mathrm{~mL}$ of $0.1 \mathrm{~N} \mathrm{HCl})$ and $57.6 \mu \mathrm{L}$ of a sodium nitrite solution $\left(7.27 \mathrm{mmol}\right.$ in $\left.5 \mathrm{~mL} \mathrm{H}_{2} \mathrm{O}\right)$ were added to the shaken gelatin solution. For nucleation, titration with sodium hydroxide $(1 \mathrm{M})$ until a $\mathrm{pH}$ of 9.5 was performed. This procedure was repeated successively four more times. The reaction mixture was then shaken at $60^{\circ} \mathrm{C}$ for an additional hour. The formed $\gamma-\mathrm{Fe}_{2} \mathrm{O}_{3}$ magnetic nanoparticles were then washed from nonmagnetic waste with deionized water by magnetic columns, via the high gradient magnetic field (HGMF) technique. ${ }^{41}$

\section{Precipitation of albumin coating onto the $\gamma-\mathrm{Fe}_{2} \mathrm{O}_{3}$ nanoparticles}

Albumin coating onto the $\gamma-\mathrm{Fe}_{2} \mathrm{O}_{3}$ nanoparticles was prepared by a precipitation mechanism as described previously. ${ }^{9,42}$ Briefly, $5 \mathrm{mg}$ of BSA or HSA were added to $4 \mathrm{~mL}$ of the $\gamma-\mathrm{Fe}_{2} \mathrm{O}_{3}$ nanoparticles dispersed in water $(2.5 \mathrm{mg} / \mathrm{mL})$. The reaction mixture was subsequently shaken at $\mathrm{pH} 9.5$ and $60^{\circ} \mathrm{C}$ for 18 hours, and then cooled gradually to room temperature. The obtained $\gamma-\mathrm{Fe}_{2} \mathrm{O}_{3} \approx \mathrm{BSA}$ or $\gamma-\mathrm{Fe}_{2} \mathrm{O}_{3} \approx \mathrm{HSA}$ nanoparticles $(\approx$ is the symbol for the albumin coating obtained by precipitation) were then washed from excess albumin with PBS by magnetic columns.

\section{Thrombin conjugation to the $\gamma-\mathrm{Fe}_{2} \mathrm{O}_{3}$ nanoparticles}

Thrombin was physically conjugated to the $\gamma-\mathrm{Fe}_{2} \mathrm{O}_{3}$ nanoparticles to increase its stability and thus to prolong its activity, as described previously. ${ }^{8,9,42}$ Briefly, $7 \mathrm{mg}$ of thrombin were added to $4 \mathrm{~mL}$ of the $\gamma-\mathrm{Fe}_{2} \mathrm{O}_{3} \approx \mathrm{BSA}$ nanoparticles dispersed in PBS $(2.5 \mathrm{mg} / \mathrm{mL})$. The reaction mixture was then shaken at $4^{\circ} \mathrm{C}$ for 18 hours. The obtained thrombin-conjugated $\gamma-\mathrm{Fe}_{2} \mathrm{O}_{3}$ nanoparticles $\left(\gamma-\mathrm{Fe}_{2} \mathrm{O}_{3} \approx \mathrm{BSA} \sim\right.$ Thrombin, $\sim$ is the symbol for physical conjugation) were then washed from excess thrombin with PBS (0.1 M, pH 7.3) by magnetic columns.

\section{bFGF conjugation to the $\gamma-\mathrm{Fe}_{2} \mathrm{O}_{3}$ nanoparticles}

bFGF was conjugated, for stabilization, to the $\gamma-\mathrm{Fe}_{2} \mathrm{O}_{3}$ nanoparticles by two main routes, covalent and physical conjugation, as follows:

\section{Covalent conjugation of bFGF}

The covalent conjugation was accomplished through the following steps:

Synthesis of DVS-derivatized $\gamma-\mathrm{Fe}_{2} \mathrm{O}_{3}$ nanoparticles $\gamma-\mathrm{Fe}_{2} \mathrm{O}_{3}$ nanoparticles were functionalized with activated double bonds via the interaction between the primary amine groups of the gelatin coating of the $\gamma-\mathrm{Fe}_{2} \mathrm{O}_{3}$ nanoparticles and DVS. Briefly, $12 \mu \mathrm{L}$ DVS were added to $1 \mathrm{~mL}$ of the $\gamma-\mathrm{Fe}_{2} \mathrm{O}_{3}$ nanoparticles dispersed in $\mathrm{BB}(3 \mathrm{mg} / \mathrm{mL}, \mathrm{pH}$ 8.4). TEA was then gradually added until a $\mathrm{pH}$ of 10.5 was reached. The reaction mixture was then shaken at $60^{\circ} \mathrm{C}$ for 18 hours. The formed DVS-derivatized $\gamma-\mathrm{Fe}_{2} \mathrm{O}_{3}$ nanoparticles were then washed from excess DVS with BB by magnetic columns.

\section{Covalent conjugation of bFGF to the DVS-derivatized} nanoparticles

Covalent conjugation of bFGF to the $\gamma-\mathrm{Fe}_{2} \mathrm{O}_{3}$ nanoparticles was accomplished via the interaction of the amino and/ or thiol groups of the growth factor with the activated double bonds on the nanoparticle surface via the Michael addition reaction. Briefly, $125 \mu \mathrm{L}$ of a bFGF PBS solution $(0.4 \mathrm{mg} / \mathrm{mL}, \mathrm{pH} 7.4)$ were added to $125 \mu \mathrm{L}$ of the DVS derivatized nanoparticles dispersed in $\mathrm{BB}(4 \mathrm{mg} / \mathrm{mL}, \mathrm{pH} 8.4)$ at a nanoparticle/bFGF weight ratio of 10 . The reaction mixture was then shaken at room temperature for 18 hours. Blocking of the residual double bonds was accomplished by adding $1 \%$ glycine $(\mathrm{w} / \mathrm{v})$ and then shaking for an additional hour. The obtained covalently bFGF-conjugated $\gamma-\mathrm{Fe}_{2} \mathrm{O}_{3}$ nanoparticles $\left(\gamma-\mathrm{Fe}_{2} \mathrm{O}_{3}-\right.$ bFGF nanoparticles; - is the symbol 
for the covalent conjugation) were then washed from nonmagnetic waste with PBS by magnetic columns.

\section{Physical conjugation of bFGF}

The physical binding of bFGF to the $\gamma-\mathrm{Fe}_{2} \mathrm{O}_{3}$ nanoparticles was accomplished by the physical interaction of bFGF with the $\gamma-\mathrm{Fe}_{2} \mathrm{O}_{3} \approx \mathrm{HSA}$ nanoparticles. Briefly, $125 \mu \mathrm{L}$ of a bFGF PBS solution $(0.4 \mathrm{mg} / \mathrm{mL}, \mathrm{pH} 7.4)$ were added to $125 \mu \mathrm{L}$ of the $\gamma-\mathrm{Fe}_{2} \mathrm{O}_{3} \approx \mathrm{HSA}$ nanoparticles dispersed in PBS $(4 \mathrm{mg} / \mathrm{mL}$, $\mathrm{pH} 8.4$ ) at a nanoparticle/bFGF weight ratio of 10 . The reaction mixture was then shaken at room temperature for 18 hours. The obtained bFGF physically-conjugated nanoparticles $\left(\gamma-\mathrm{Fe}_{2} \mathrm{O}_{3} \sim \mathrm{bFGF}\right)$ were then washed from nonmagnetic waste with PBS by magnetic columns.

\section{Binding yield and concentration of thrombin and bFGF bound to the $\gamma-\mathrm{Fe}_{2} \mathrm{O}_{3}$ nanoparticles}

The concentration of the thrombin and the bFGF conjugated to the $\gamma-\mathrm{Fe}_{2} \mathrm{O}_{3}$ nanoparticles were determined by measuring the unbound thrombin or bFGF using the Bradford assay ${ }^{43}$ and subtracting it from the initial concentration. The binding yield was calculated by multiplying the ratio between the concentration of the bound protein to the initial concentration by 100 .

\section{Thrombin and bFGF leakage extent}

The leakage of bound thrombin and bFGF from the $\gamma-\mathrm{Fe}_{2} \mathrm{O}_{3}$ nanoparticles into PBS containing 4\% HSA (equivalent to the physiologic concentration of HSA) was evaluated using the following procedure: thrombin-conjugated nanoparticles and bFGF-conjugated nanoparticles dispersed in PBS containing 4\% HSA (2 mg nanoparticles/mL) were shaken at room temperature for 7 hours. Then, the nanoparticles were extracted from the supernatant using the HGMF technique. The concentration of the bFGF leaked to the supernatant was measured using human bFGF ELISA kit (Biotest, Israel). The thrombin leakage extend was measured as described previously. ${ }^{9}$

\section{Isolation of NOM cells from adult rats}

The NOM cells were derived from the olfactory mucosa of Lewis inbred rats (Harlan, Israel), as described previously. ${ }^{38}$ Adult Lewis rats (250 g) were nasally infused with $0.7 \%$ Triton $\mathrm{X}-100$ in both nostrils 4 days prior to their scarification. The Triton X-100 causes a moderate damage to the neuroepithelium, which thereby encourages a large number of neurons to be obtained, following an active reconstruction by the neuronal precursor cells in a culture. Prior to the NOM dissection, cardiac perfusion of the rats was made with $60 \mathrm{~mL}$ of saline. All the experiments were carried out under the Animals' Care and Use Committee, which is recognized by the Israeli authorities for animal experimentation. The dissected NOM tissue was fragmented, separated from the bones under a stereomicroscope and washed several times with an ice-cold culture medium (composed of 90\% DMEM-F12, 10\% FCS, 6 g/L D-glucose, $2 \mathrm{nM}$ glutamine and $25 \mu \mathrm{g} / \mathrm{mL}$ gentamicin). The NOM fragments were then enzymatically dissociated in a $0.25 \%$ trypsin-EDTA solution for 30 minutes.

\section{Cultivation of adult rat NOM cells in the magnetic fibrin hydrogel scaffolds}

The NOM cells were seeded and grown in the magnetic fibrin hydrogel scaffolds by two tissue cultivation methods. In the first method, dissociated cells were grown first as a two-dimensional stationary culture for three weeks. ${ }^{38}$ The cells were then transferred and seeded in the magnetic fibrin hydrogel scaffolds, in the absence or presence of free or conjugated bFGF, as described below. In the second method, the NOM cells were cultured for a week in suspension attached to positively-charged chitosan microcarriers (MCs), in the absence or presence of free or conjugated bFGF nanoparticles. Subsequently, the formed floating cells/growth factors/MCs aggregates were transferred and seeded in the magnetic fibrin scaffold. The detailed preparation procedure of the NOM cells/free or conjugated bFGF nanoparticles/ MCs aggregates is described below.

\section{Preparation of NOM cells/free or conjugated bFGF nanoparticle/MCs aggregates}

$0.2 \mathrm{~mL}$ of $2 \%(\mathrm{w} / \mathrm{v})$ chitosan MCs (4 mg) suspended in PBS were added to each well of a 24-well culture plate. Subsequently, each well was enriched with $10 \mu \mathrm{L}(10 \mu \mathrm{g}$ bound $\mathrm{bFGF} /$ well) of the $\gamma-\mathrm{Fe}_{2} \mathrm{O}_{3}$-bFGF nanoparticles dispersed in $\mathrm{PBS}$, and the mixtures were then incubated at $37^{\circ} \mathrm{C}$ for 1 hour. To each well, $500 \mu \mathrm{L}$ of the NOM cell suspension were then added $\left(5 \times 10^{6}\right.$ cells/well $)$ and incubated with the $\gamma-\mathrm{Fe}_{2} \mathrm{O}_{3}$-bFGF nanoparticle/MCs aggregates at $37^{\circ} \mathrm{C}$ for 1 hour. Then, each well received $1.3 \mathrm{~mL}$ of culture medium and were incubated for an additional 7 days. Subsequently, $100 \mu \mathrm{L}$ of the cell $/ \gamma-\mathrm{Fe}_{2} \mathrm{O}_{3}$-bFGF nanoparticle/MCs aggregates of each well were transferred and seeded in the fibrin scaffolds, as described below. Similar experiments were also performed in the presence of naked $\gamma-\mathrm{Fe}_{2} \mathrm{O}_{3}$ nanoparticles 
(control), $\gamma-\mathrm{Fe}_{2} \mathrm{O}_{3} \sim \mathrm{bFGF}$ nanoparticles, and different concentrations of the free bFGF, eg, the same concentration as the conjugated nanoparticles and 5 and 10 times higher.

\section{Preparation of the magnetic fibrin hydrogel scaffolds and cultivation of the dissociated cells in the scaffolds}

The following components were added to each well of the 24-well culture plate: $100 \mu \mathrm{L}$ of the cell suspension $\left(1 \times 10^{6}\right.$ cells/well), $150 \mu \mathrm{L}$ of bovine fibrinogen $(100 \mathrm{mg} / \mathrm{mL}$ PBS), $155 \mu \mathrm{L}$ of a culture medium, $60 \mu \mathrm{L}$ of a $\mathrm{CaCl}_{2}$ aqueous solution $(25 \mathrm{mM}), 5 \mu \mathrm{L}$ of Factor XIII $(200 \mu \mathrm{g} / \mathrm{mL}$ PBS $)$ and $8 \mu \mathrm{L}$ of aprotinin $(6720 \mathrm{KUI} / \mathrm{mL} \mathrm{PBS})$. In the experiments aimed at studying the effect of the nonconjugated $\gamma-\mathrm{Fe}_{2} \mathrm{O}_{3}$ nanoparticles (control) and the free or conjugated-bFGF on the proliferation and differentiation of the NOM cells, $\gamma-\mathrm{Fe}_{2} \mathrm{O}_{3}$ nanoparticles and free or conjugated growth factors were also added to each well $(0.5 \mu \mathrm{g}$ of free or conjugated factor/well). Finally, $50 \mu \mathrm{L}$ of the thrombin-conjugated nanoparticles (360 $\mu \mathrm{g}$ of thrombin bound to $0.5 \mathrm{mg}$ of nanoparticles $/ \mathrm{mL}$ PBS) were added to each well. The mixture was then allowed to clot (in about 2 minutes). After clotting, $1 \mathrm{~mL}$ of the culture medium was added to each fibrin clot, and the cells were incubated at $37^{\circ} \mathrm{C}$ in a $\mathrm{CO}_{2}$ incubator. The culture medium was changed every 3 days. The cultures were performed in triplicate for each type of treatment.

For a quantitative determination of the effect of the free/conjugated bFGF on the growth of the NOM cells in the magnetic fibrin scaffolds, three random nonoverlapping pictures of each culture were taken on different days of the cultivation, using phase-contrast microscopy (Olympus BX60 F5 microscope; Eisenberg Bros, Israel). The cells were then counted using ImageJ software, and the average and the standard deviations were calculated.

\section{Cultivation of the cell/bFGF/MCs aggregates in the magnetic fibrin hydrogel scaffolds}

This cultivation process was performed similarly to the cultivation process described above, substituting the $100 \mu \mathrm{L}$ of the dissociated cells suspension and the free or conjugated factors for $100 \mu \mathrm{L}$ of the cell/bFGF/MCs aggregates' suspension.

\section{Immunofluorescent staining}

The characterization of the NOM cells was accomplished through immunofluorescent staining. Samples to be analyzed were fixed for 15 minutes with $4 \%$ of paraformaldehyde at room temperature and then washed three times with PBS. The fixed cells were permeabilized with $0.1 \%$ of Triton X-100 in PBS and then immunoblocked (to avoid nonspecific staining) with a background buster solution (Innovex Biosciences, Richmond, CA) for 1 hour at room temperature. The samples were then incubated overnight at $4^{\circ} \mathrm{C}$ with the respective primary antibodies in PBS. The following primary antibodies were used: rabbit anti-tubulin beta 3, clone EP1331Y ( $\beta 3$ Tub, neuronal marker, 1:200, catalog \#NB110-576-10; Novus Biologicals); rabbit antineurofilament medium (NF, neuronal marker, 1:400, catalog \#NB300-133; Novus Biologicals), mouse anti-S100B (glia marker, 1:80, catalog \# DM111-05; Acris Antibodies) and mouse anti-nestin, clone rat-401 (neurofilament protein, neuronal precursor marker, 1:100, catalog \#sc-33677; Santa Cruz Biotechnology). The samples were subsequently rinsed with PBS and incubated overnight at $4^{\circ} \mathrm{C}$ with the appropriate dye-conjugated secondary antibodies (DyLight 649-conjugated donkey anti-mouse IgG, 1:200, catalog \#715-495-151; DyLight 488-conjugated donkey anti-rabbit IgG, 1:200, catalog \#711-485-152; both from Jackson ImmunoResearch). Finally, the samples were washed again with PBS, and the nuclei of the cells were stained (blue) and mounted with DAPI-Fluoromount-G. Control experiments were performed similarly, but in the absence of the primary antibodies. All of the images were observed by a Nikon $90 \mathrm{i}$ microscope (Nikon, USA) and processed using the Cell-R software under the same conditions (exposure time and magnification).

\section{Cell adhesion}

Purified NOM cells were seeded in 24-well culture plates on top of the magnetic fibrin hydrogel scaffolds, or in PLLcoated wells, or in noncoated wells (control). The fibrin coating was performed as follow: a mixture containing $120 \mu \mathrm{L}$ of fibrinogen $(100 \mathrm{mg} / \mathrm{mL}$ PBS $), 225 \mu \mathrm{L}$ of a culture medium, and $50 \mu \mathrm{L}$ of a $\mathrm{CaCl}_{2}$ aqueous solution $(25 \mathrm{mM})$ was added to each well. Then, $40 \mu \mathrm{L}$ of the thrombin-conjugated nanoparticles ( $360 \mu \mathrm{g}$ of thrombin bound to $0.5 \mathrm{mg}$ nanoparticles/mL PBS) were added to each well, and the mixture was allowed to clot (in a few minutes). The PLL coating was performed as follow: $500 \mu \mathrm{L}$ of a PLL solution $(0.1 \%$ in PBS) were add to each well and incubated at $37^{\circ} \mathrm{C}$ for 1 hour. The coated wells were then washed three times with the culture medium. After completion of the coating process, ten thousand $\left(1 \times 10^{4}\right) \mathrm{NOM}$ cells suspended in $0.5 \mathrm{~mL}$ of the culture medium were seeded in each uncoated and coated well. Two, 4, 6, and 24 hours after the cell culturing, the wells were carefully rinsed three times with the culture medium to remove the nonadherent cells. To quantify the number 
of adherent cells, pictures of five random nonoverlapping fields of each well were taken using a phase-contrast microscope. The attached cells were then counted using ImageJ software, and the average and the standard deviations were calculated.

\section{Characterization}

\section{Electron microscopy}

Transmission electron microscopy (TEM) pictures were obtained with a FEI Tecnai C2 BioTWIN electron microscope with a $120 \mathrm{kV}$ accelerating voltage. High-resolution TEM (HRTEM) images were obtained by employing a JEOL-2100 device with a $200 \mathrm{kV}$ accelerating voltage. The nanoparticle samples for TEM and HRTEM were prepared by placing a drop of a diluted sample on a 400-mesh carboncoated copper grid or on a carbon-coated copper lacy grid. The average size and size distribution of the dry particles were then determined by measuring the diameter of more than 200 particles with image analysis software, AnalySIS Auto (Soft Imaging System GmbH, Germany). Samples of the magnetic fibrin scaffolds for TEM analysis were obtained as follows: the reagents used to prepare the fibrin hydrogels were mixed, as described in the experimental part, in the absence of the cells and diluted $100 \times$ in PBS. A drop of the diluted sample was then placed carefully on a 400mesh carbon-coated copper grid, and allowed to form a thin layer of fibrin fibers for 1 minute. The excess solution was then removed with a filter paper. The $3 \mathrm{D}$ growth of the cells within the magnetic fibrin scaffolds was demonstrated by a scanning electron microscope (SEM) Model FEI Quanta 250 FEG (OR). The samples for the SEM analysis were prepared as follow: following a desired period of cultivation, the cells in the scaffolds were fixed with $4 \%$ of glutaraldehyde in a PBS solution for 1 hour and then washed from excess reagents three times with PBS. In order to view the cells inside the scaffolds, the samples were cut into pieces using a scalpel blade. Then the fixed slices were dehydrated in series of $50 \%, 70 \%, 80 \%, 90 \%$, and $100 \%$ ethanol/water solutions (v/v) for 10 minutes each. The residual ethanol was then removed using a series of $50 \%, 75 \%$, and $100 \%$ (×3) Freon solutions in ethanol, for 10 minutes each. Finally, the samples were left for a few seconds to dry under air. The dried samples were mounted on aluminum stubs, sputtercoated with carbon, and viewed with the SEM. Surface morphology of the cell/nanoparticle/MCs aggregates was also characterized with a SEM. The samples were fixed, as described above, and sputter-coated with gold in vacuum before viewing.

\section{Magnetic measurements}

Magnetic measurements were performed at room temperature using a vibrating sample magnetometer (VSM; Oxford Instruments, UK).

\section{Statistical analysis}

Statistical analysis was performed by Student's $t$-test. The results are expressed as mean \pm standard deviation (SD). $P<0.05$ was accepted as indicating the statistical significance.

\section{Results and discussion}

In the present study, the bFGF and the thrombin were stabilized through their conjugation to $\gamma-\mathrm{Fe}_{2} \mathrm{O}_{3}$ nanoparticles of narrow size distribution $(19.8 \pm 4.7 \mathrm{~nm})$ developed in our laboratory, as described previously. ${ }^{10,40}$

Figure 1 describes the general scheme through which the physical conjugation of thrombin and the physical and covalent conjugation of bFGF onto the surface of the $\gamma-\mathrm{Fe}_{2} \mathrm{O}_{3}$ nanoparticles were performed. Figure 1 illustrates that the covalent conjugation of bFGF to the $\gamma-\mathrm{Fe}_{2} \mathrm{O}_{3}$ nanoparticles is based on the presence of gelatin thin layer on the surface of these nanoparticles, as shown in Figure 2A and B and described previously. ${ }^{44}$ The surface gelatin provides functional groups, eg, primary amines and hydroxyls, through which functionalization of these nanoparticles with activated double bonds, via the Michael addition reaction, was accomplished with excess DVS. The residual activated double bonds of the $\gamma-\mathrm{Fe}_{2} \mathrm{O}_{3}-$ DVS nanoparticles were then used for covalent binding of the bFGF to the surface of the nanoparticles, again via the Michael addition reaction. Blocking of the remaining double bonds of the $\gamma-\mathrm{Fe}_{2} \mathrm{O}_{3}-\mathrm{bFGF}$ nanoparticles was done with glycine, according to the experimental part.

The physical conjugation of thrombin and bFGF was performed in two main steps: the first step consisted of coating the nanoparticles dispersed in an aqueous continuous phase with albumin (BSA or HSA) by a precipitation mechanism, according to the experimental part. The second step consisted of the physical conjugation of the thrombin or bFGF onto the albumin-coated $\gamma-\mathrm{Fe}_{2} \mathrm{O}_{3}$ nanoparticles. The physical conjugation of these bioactive molecules onto the albumin-coated layer is based on the fact that albumin is a carrier protein with a high affinity to various exogenous and endogenous compounds. ${ }^{45,46}$

The binding yield of albumin precipitated on the surface of the $\gamma-\mathrm{Fe}_{2} \mathrm{O}_{3}$ nanoparticles following addition of $5 \mathrm{mg}$ albumin to $10 \mathrm{mg}$ nanoparticles dispersed in PBS is $99.4 \%$ (496.7 $\mu \mathrm{g}$ albumin/mg nanoparticles), as determined by Bradford assay., ${ }^{9,43}$ 


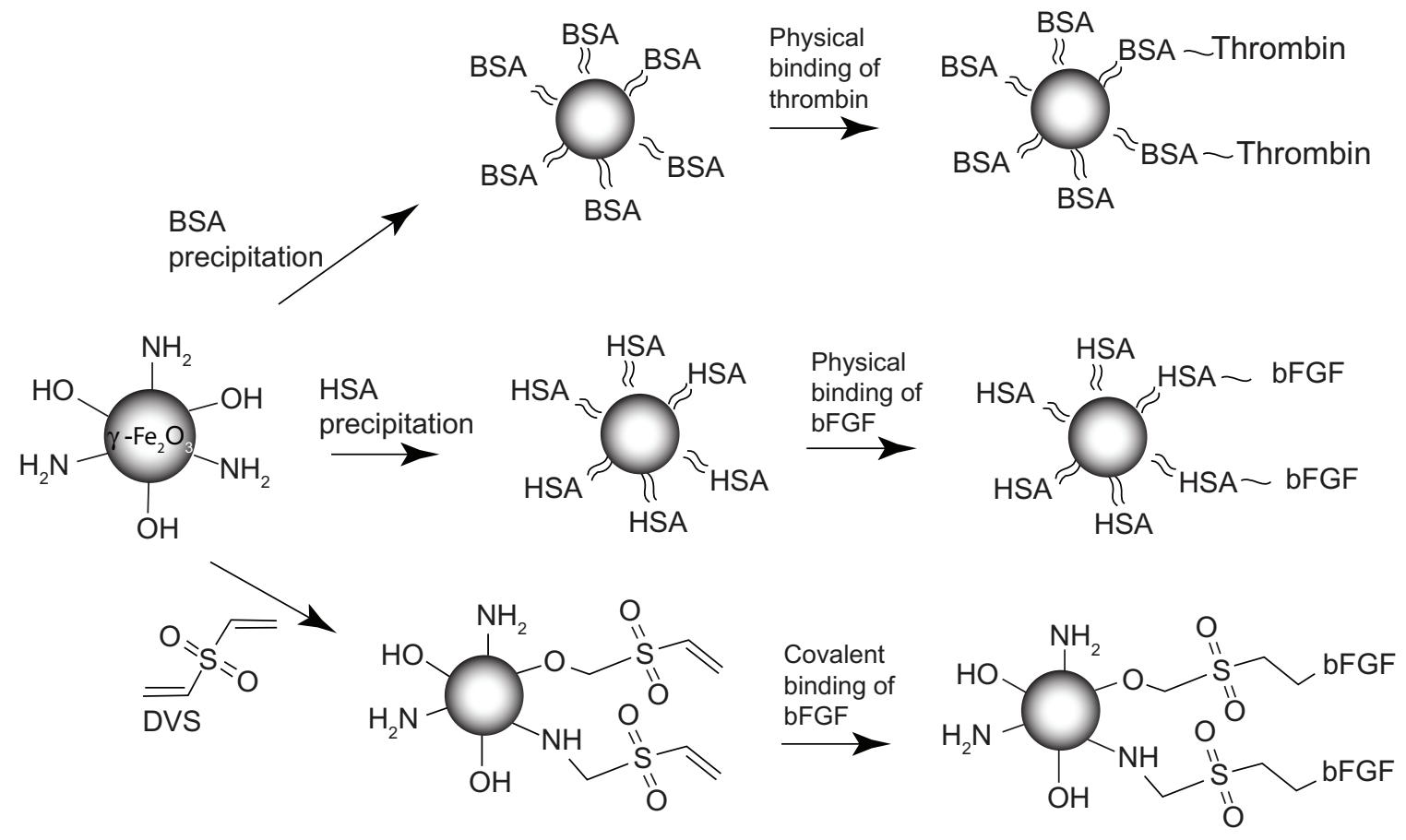

Figure I Physical and covalent conjugation of thrombin and bFGF to the $\gamma$-Fe ${ }_{2} \mathrm{O}_{3}$ nanoparticles. $\approx, \sim$, and - are symbols for precipitation, physical binding and covalent binding of various ligands to the $\gamma-\mathrm{Fe}_{2} \mathrm{O}_{3}$ nanoparticles, respectively.

Abbreviation: bFGF, basal fibroblast growth factor.

The concentrations and the conjugation yields of the thrombin and the bFGF bound to the $\gamma-\mathrm{Fe}_{2} \mathrm{O}_{3}$ nanoparticles are shown in Table 1. Table 1 indicates that the thrombin-binding yield is very high (97.5\%). In addition, Table 1 shows that the binding yield of both the covalent and physical conjugation of the bFGF to the nanoparticles is similar and very high ( $95.4 \%$ and $96.9 \%$, respectively). The high binding yields values of the covalent binding may indicate that in addition to the covalent binding, physical adsorption of the bFGF onto the surface of the nanoparticles may also be involved.

The thrombin leakage from the $\gamma-\mathrm{Fe}_{2} \mathrm{O}_{3} \approx \mathrm{BSA} \sim$ thrombin nanoparticles into PBS containing 4\% HSA was negligible. ${ }^{9}$ Similarly, the leakage of both the covalently and the physically bound bFGF into PBS containing 4\% HSA was not detected by the bFGF ELISA kit.

The organic coatings on the $\gamma-\mathrm{Fe}_{2} \mathrm{O}_{3}$ nanoparticles were visualized by HRTEM. Figure 2 demonstrates the gelatin, gelatin $\approx \mathrm{BSA}$, and the gelatin $\approx \mathrm{BSA} \sim$ thrombin coatings on the crystalline core of the $\gamma-\mathrm{Fe}_{2} \mathrm{O}_{3}, \gamma-\mathrm{Fe}_{2} \mathrm{O}_{3} \approx \mathrm{BSA}$, and $\gamma-\mathrm{Fe}_{2} \mathrm{O}_{3} \approx \mathrm{BSA} \sim$ thrombin nanoparticles, respectively. Careful measurements indicated that the gelatin, BSA, and thrombin thicknesses under the described experimental conditions were: $3.8 \pm 1.1,0.8 \pm 0.3$ and $3.1 \pm 0.4 \mathrm{~nm}$, respectively.

In previous studies, the thrombin-conjugated $\gamma-\mathrm{Fe}_{2} \mathrm{O}_{3}$ nanoparticles were used for hemostasis and wound healing. . $^{9,42}$ In the present study, these nanoparticles were used for the fabrication of the magnetic fibrin hydrogel scaffolds. The fibrin hydrogel scaffolds were prepared by mixing thrombinconjugated nanoparticles dispersed in an aqueous solution with a fibrinogen aqueous solution containing $\mathrm{CaCl}_{2}$, Factor XIII, aprotinin, growth factor-conjugated $\gamma-\mathrm{Fe}_{2} \mathrm{O}_{3}$ nanoparticles, and the desired cells for cultivation.
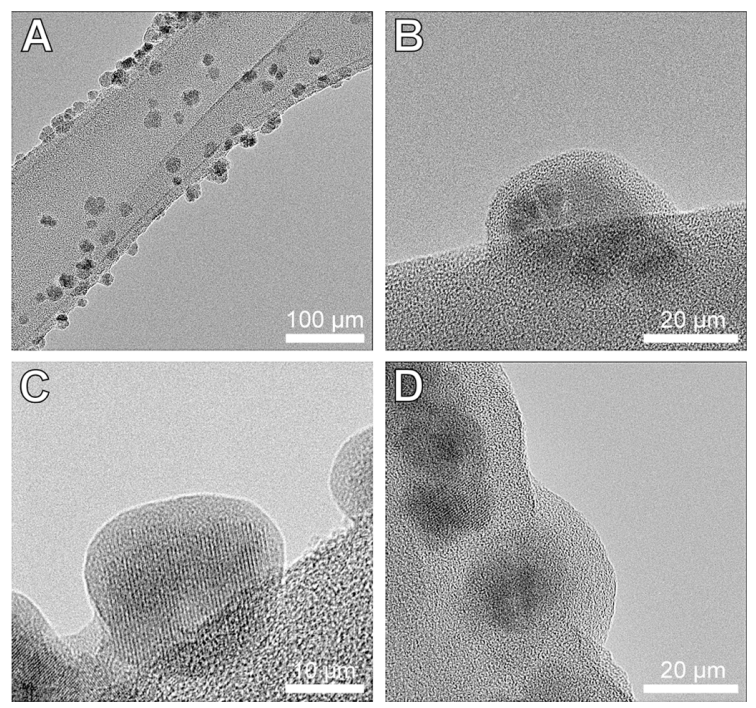

Figure 2 HRTEM images of the $\gamma-\mathrm{Fe}_{2} \mathrm{O}_{3}(\mathbf{A}$ and $\mathbf{B}), \gamma-\mathrm{Fe}_{2} \mathrm{O}_{3} \approx \mathrm{BSA}(\mathbf{C})$ and $\gamma-\mathrm{Fe}_{2} \mathrm{O}_{3} \approx$ $\mathrm{BSA} \sim$ Thrombin (D) nanoparticles placed on lacy grids. These images demonstrate the gelatin $(\mathbf{A}$ and $\mathbf{B})$, gelatin $\approx \mathrm{BSA}(\mathbf{C})$ and gelatin $\approx \mathrm{BSA} \sim$ Thrombin $(\mathbf{D})$ coatings on the crystalline $\gamma-\mathrm{Fe}_{2} \mathrm{O}_{3}$ core of the nanoparticles.

Abbreviations: HRTEM, high-resolution transmission electron microscopy; BSA bovine serum albumin. 
Table I The concentrations and the conjugation yields of the thrombin and the bFGF bound to the $\gamma-\mathrm{Fe}_{2} \mathrm{O}_{3}$ nanoparticles

\begin{tabular}{lll}
\hline $\begin{array}{l}\text { The bioactive } \\
\text { nanoparticles }\end{array}$ & $\begin{array}{l}{[\text { Bound protein }]} \\
{\left[\mu \mathbf{g}_{\text {(protein) }} I\right.} \\
\left.\mathbf{m g}_{\text {(nanoparticles) }}\right]\end{array}$ & $\begin{array}{l}\text { Conjugation } \\
\text { yield } \\
\text { (weight\%) }\end{array}$ \\
\hline$\gamma-\mathrm{Fe}_{2} \mathrm{O}_{3} \approx \mathrm{BSA} \sim$ Thrombin & $97.5 \pm 1.4$ & $97.5 \pm 1.4$ \\
$\gamma-\mathrm{Fe}_{2} \mathrm{O}_{3}-\mathrm{bFGF}$ & $95.4 \pm 1.9$ & $95.4 \pm 1.9$ \\
$\gamma-\mathrm{Fe}_{2} \mathrm{O}_{3} \approx \mathrm{HSA} \sim \mathrm{bFGF}$ & $96.9 \pm 1.6$ & $96.9 \pm 1.6$ \\
\hline
\end{tabular}

Notes: The calculations of the conjugation yield and concentration were accomplished as described in the experimental section. $\sim$ and - are symbols for physical and covalent bindings, respectively of the bFGF to the $\gamma-\mathrm{Fe}_{2} \mathrm{O}_{3}$ nanoparticles.

Abbreviations: bFGF, basal fibroblast growth factor; BSA, bovine serum albumin; HSA, human serum albumin.

It should be noted that the magnetic scaffolds described in this manuscript are different from those described in the literature. To date, magnetic scaffolds were prepared by insertion of nonactive iron oxide nanoparticles to nonmagnetic scaffolds, eg, by dip-coating of porous collagen or hydroxyapatite scaffolds in aqueous ferrofluids containing iron oxide nanoparticles, ${ }^{17,19}$ or by in situ development of iron oxide nanoparticles in hydrogels. ${ }^{20,21}$ In contrast, our magnetic scaffolds were prepared by in situ interaction of magnetic thrombin-conjugated nanoparticles with fibrinogen.

In this study, adult rat NOM cells were chosen for culture in the scaffolds. Immunofluorescent staining of the NOM cells grown in stationary cultures in two dimensions, before being transferred to the magnetic fibrin scaffolds (Figure 3), indicates that the NOM cells cultures are composed of various cells: glial OECs (positively stained with mouse anti-S100B), neuronal cells (positively stained with rabbit anti- $\beta 3$ Tub and rabbit anti-NF), and stem and progenitor cells (positively stained with mouse anti-nestin). These results are in agreement with previous publications indicating that NOM tissue is a heterogeneous complex. ${ }^{35}$ Moreover, recent studies indicate that the transplantation of the "pure" OEC population is insufficient for attaining complete recovery of spinal cord injuries. A better recovery of the structure, and sensory and motor functions of an injured spinal cord can be attained using a complex of NOM cells, including, apart from the OECs, multipotent stem and progenitor cells. ${ }^{35}$

The clotting time of the fibrin hydrogel depends mainly on the concentration of the fibrinogen, thrombin and $\mathrm{CaCl}_{2} .5,6,47$ In our developed formulation, the clotting time is about 2 minutes. This period of time enables to be mixed the NOM cells with all the ingredients of the fibrin hydrogel scaffolds, and inserted into silicon rubber molds of desired shapes, or in tubes, before clotting. Generally, the fibrin hydrogel structure may vary between the extremes of "fine, transparent" and "coarse, turbid". ${ }^{48}$ The fibrin gel structure is mainly determined by the thrombin and fibrinogen concentrations, but is also affected by other factors such as proteins and ions. For example, in the presence of albumin or fibronectin the morphology of the fibrin fiber network is coarser than in a purified fibrinogen-thrombin system. ${ }^{49}$ Calcium ions concentration is also such a modulating factor. ${ }^{5,49}$ Our produced magnetic fibrin hydrogel scaffolds have a high degree of transparency and a 3D structure. The transparency of the
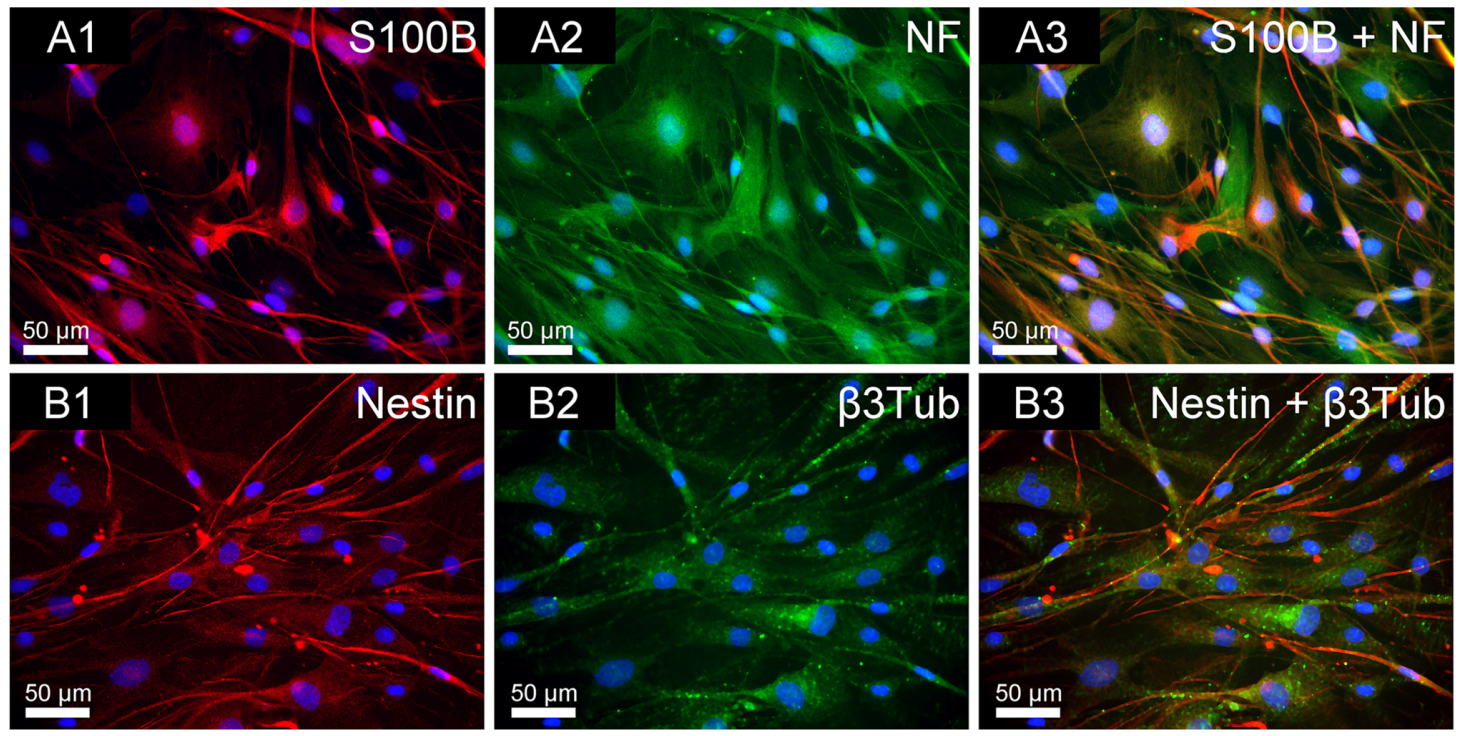

Figure $3 \mathrm{Immunofluorescence} \mathrm{double} \mathrm{staining} \mathrm{of} \mathrm{NOM} \mathrm{cells} \mathrm{cultured} \mathrm{for} 2 \mathrm{I}$ days in 2D stationary culture, prior to their seeding in the magnetic fibrin scaffolds. (AI) SI00B (glia marker in red); (A2) NF (neuronal marker in green); (A3) merge of SI00B and NF. (BI) Nestin (neuronal precursor marker in red); (B2) $\beta 3$ Tub (neuronal marker in green); (B3) merge of nestin and $\beta 3$ Tub. The nuclei of the cells were dyed in blue with DAPI.

Abbreviations: NOM, nasal olfactory mucosa; 2D, two-dimensional; SI00B, I00\% soluble calcium-binding protein B; NF, neurofilament; $\beta 3$ Tub, beta III tubulin; DAPI, 4',6-diamindo-2-phenylindole. 
scaffolds enables a microscopic observation of the cells during their 3D growth in the scaffolds by light or a fluorescence microscope. However, it should be noted that when using a standard phase-contrast microscope it is possible to obtain sharp images only of cells at a particular plane of focus and not of the entire 3D pattern within the scaffolds.

To illustrate the efficiency of the magnetic fibrin hydrogel scaffolds as a matrix for cell adhesion, purified NOM cells were seeded on top of the fibrin hydrogel scaffolds, in comparison to their seeding on PLL-coated dishes or noncoated culture plates (control). Figure 4 demonstrates that the magnetic fibrin hydrogel scaffolds promoted the adhesion of the NOM cells significantly better than the PLL and the noncoated control surfaces $(P<0.01)$. These measurements indicate that in $2,4,6$, and 24 hours postseeding, the amount of cells adhering to the fibrin scaffolds was $2.7,3.0,3.4$, and 3.6 times higher than that obtained for the PLL group, and 6.2, 3.3, 3.4, and 3.6 times higher than that of the control group, respectively. The advantage of the magnetic fibrin hydrogel scaffolds for cell adhesion is probably due to the fibrin component, which naturally contains sites for cell binding. Therefore, it has been investigated as a substrate for cell adhesion, spreading, migration, and proliferation. ${ }^{5,6}$ It should be noted that the cell adhesion capacity of the scaffolds can be enhanced by the integration of adhesive molecules such as laminin and fibronectin within the scaffolds. ${ }^{3}$
The magnetic fibrin hydrogel scaffolds are biodegradable. The duration of the degradability can be vary between a few days up to a few months, depending on various factors, eg, the density of seeded cells as well as the optimal concentrations of fibrinogen, thrombin, $\mathrm{Ca}^{++}$ions, factor XIII, and aprotinin (a proteases inhibitor that slows down the degradation of the fibrin scaffold).$^{50}$ The concentrations of these components also affect cell proliferation, migration, and differentiation within the fibrin scaffolds. ${ }^{47,50,51} \mathrm{In}$ experiments that lasted over a month, we illustrated that our developed fibrin scaffolds containing the NOM cells in it are stable. During that time the NOM cells were grown in the scaffolds, proliferated and differentiated into neuron-like bipolar cells organized in 3D interconnected networks, as shown by SEM image (Figure 5), and later by phase-contrast microscopy (Figure 11).

The detailed-structure of the magnetic fibrin hydrogel scaffolds is illustrated by high magnification SEM and TEM images, as shown in Figure 5. The SEM image indicates that the fibrin hydrogel scaffolds are composed of a 3D porous fiber network. The TEM image shows the attachment of a few thrombin-conjugated nanoparticles on the external surface of the fibrin fibers. The other part of the nanoparticles is probably encapsulated within the fibrin scaffolds. We presume that the porous structures facilitate oxygen penetration into the scaffolds, and the network structure enables the 3D growth of the cells along the fibers.

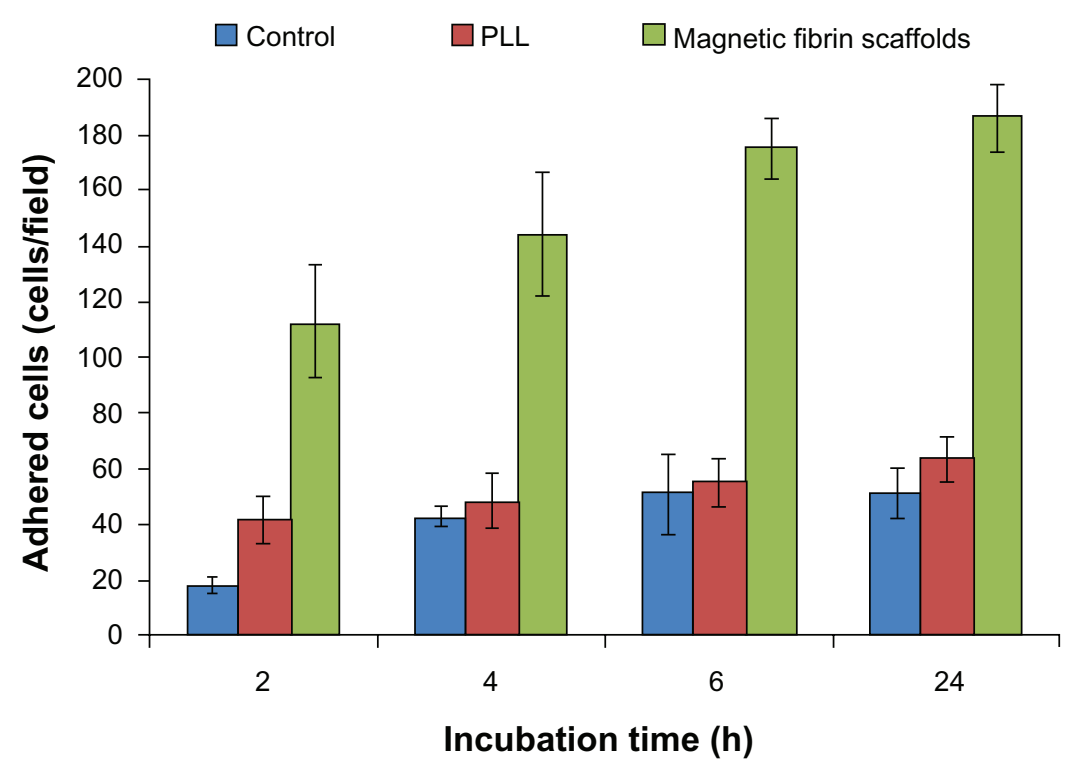

Figure 4 Quantitative analysis of the NOM cells adhered to the magnetic fibrin scaffold coating, or PLL coating, or uncoated culture plate (control) at different time intervals post-seeding. NOM cells were seeded in 24-well culture plates coated with the magnetic fibrin hydrogel or with PLL, or uncoated wells. 2, 4, 6, and $24 \mathrm{~h}$ after the seeding the wells were rinsed with the culture medium to remove the non-adherent cells. Quantification of the number of the adherent cells was performed by phase-contrast microscope images of five random non-overlapping fields of each well. Cells were then counted using Imagej software, and the average and the standard deviation were calculated. Abbreviations: NOM, nasal olfactory mucosa; PLL, poly-L-lysine. 

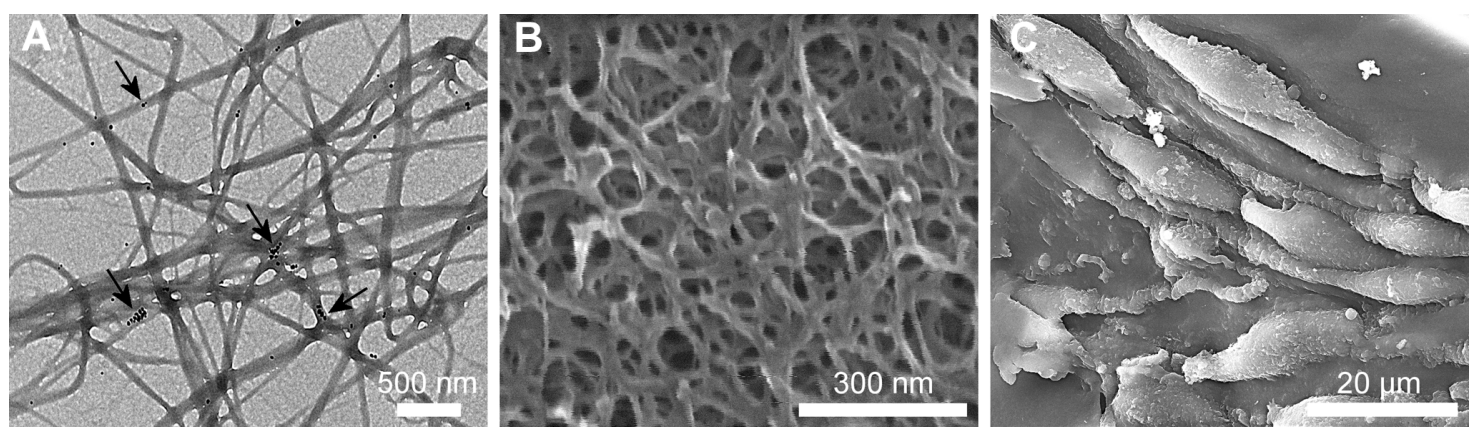

Figure 5 TEM (A) and SEM (B and $\mathbf{C}$ ) images of the magnetic fibrin hydrogel scaffolds in the absence (A and $\mathbf{B}$ ) or presence (C) of NOM cells. The magnetic fibrin scaffolds were prepared by the interaction of thrombin-conjugated $\gamma-\mathrm{Fe}_{2} \mathrm{O}_{3}$ nanoparticles with fibrinogen as described in the experimental part. The arrows in (A) point to the thrombin-conjugated nanoparticles.

Abbreviations: NOM, nasal olfactory mucosa; SEM, scanning electron microscopy; TEM, transmission electron microscopy.

The magnetic properties of the fibrin hydrogel scaffolds were examined by VSM (Figure 6). Figure 6A exhibits the magnetic properties of the fibrin hydrogel scaffolds containing 0.15 weight $\%$ iron oxide nanoparticles, prepared by the interaction of thrombin-conjugated $\gamma$ - $\mathrm{Fe}_{2} \mathrm{O}_{3}$ nanoparticles with fibrinogen, as described in the experimental section. Figure 6B exhibits the magnetic properties of the fibrin hydrogel scaffolds containing 1.5 weight $\%$ of the iron oxide nanoparticles. These scaffolds were prepared by the addition of bFGF-conjugated $\gamma-\mathrm{Fe}_{2} \mathrm{O}_{3}$ nanoparticles to the magnetic fibrin scaffolds before their clotting, as described in the experimental section. The magnetization curves shown in Figure 6 illustrate that at room temperature both $M(H)$ plots reach saturation around 2000 Oe. The saturation magnetizations of the fibrin scaffolds containing 0.15 (A) and 1.5 (B) weight $\%$ of the iron oxide nanoparticles are 0.05 and $0.5 \mathrm{emu} / \mathrm{g}$, respectively. The 10 -fold increase in the magnetization of these scaffolds is probably attributed to the 10 -fold increase in concentration of the iron oxide nanoparticles within the scaffolds. In other words, the magnetization is proportional to the concentrations of the iron oxide nanoparticles within the scaffolds: the higher the concentration the higher is the saturation magnetization. The magnetic properties of the fibrin hydrogel scaffolds were also demonstrated in a simple way, by attracting both scaffolds described above to a common magnet, as shown in Figure 7.

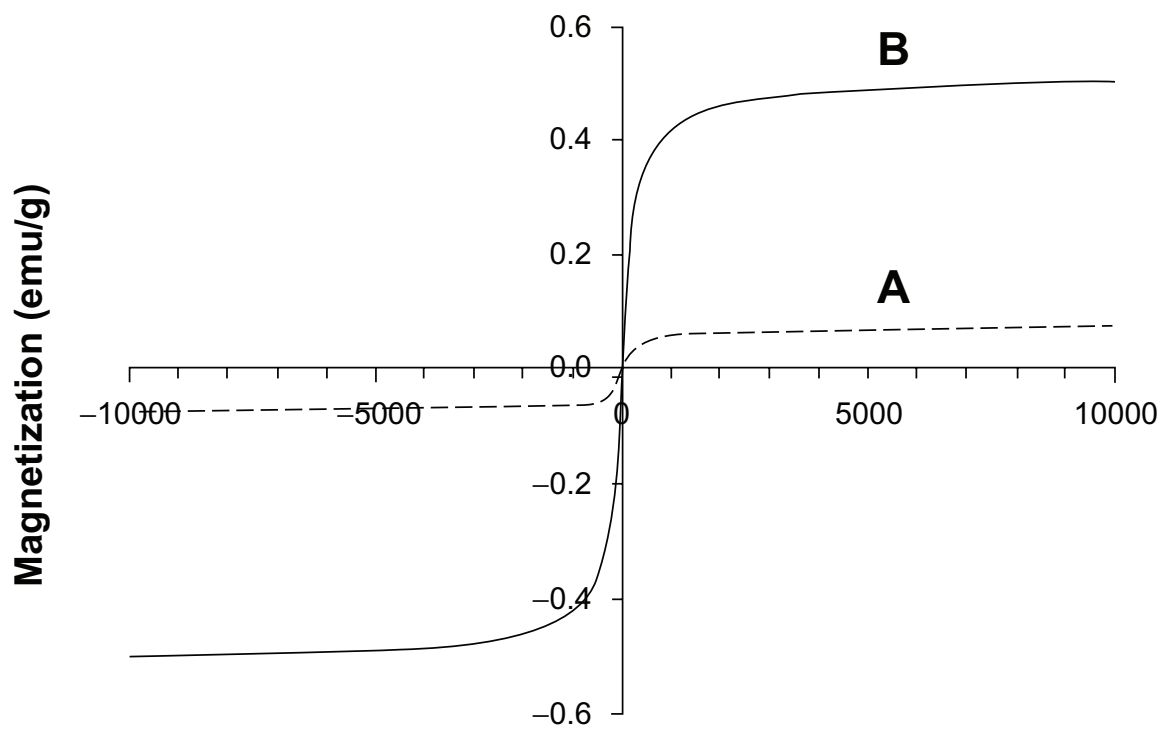

Magnetic field (Oe)

Figure 6 Magnetization curves at room temperature of the magnetic fibrin hydrogel scaffolds containing $0.15 \%(\mathbf{A})$ and $1.5 \%(\mathbf{B}) \gamma$-Fe $\mathrm{O}_{3}$ nanoparticles. (A) represents the magnetic fibrin hydrogel scaffolds containing the thrombin-conjugated $\gamma$ - $\mathrm{Fe}_{2} \mathrm{O}_{3}$ nanoparticles only; (B) represents the magnetic fibrin hydrogel scaffolds containing in addition to the thrombin conjugated nanoparticles also the bFGF conjugated $\gamma-\mathrm{Fe}_{2} \mathrm{O}_{3}$ nanoparticles.

Abbreviation: bFGF, basal fibroblast growth factor. 

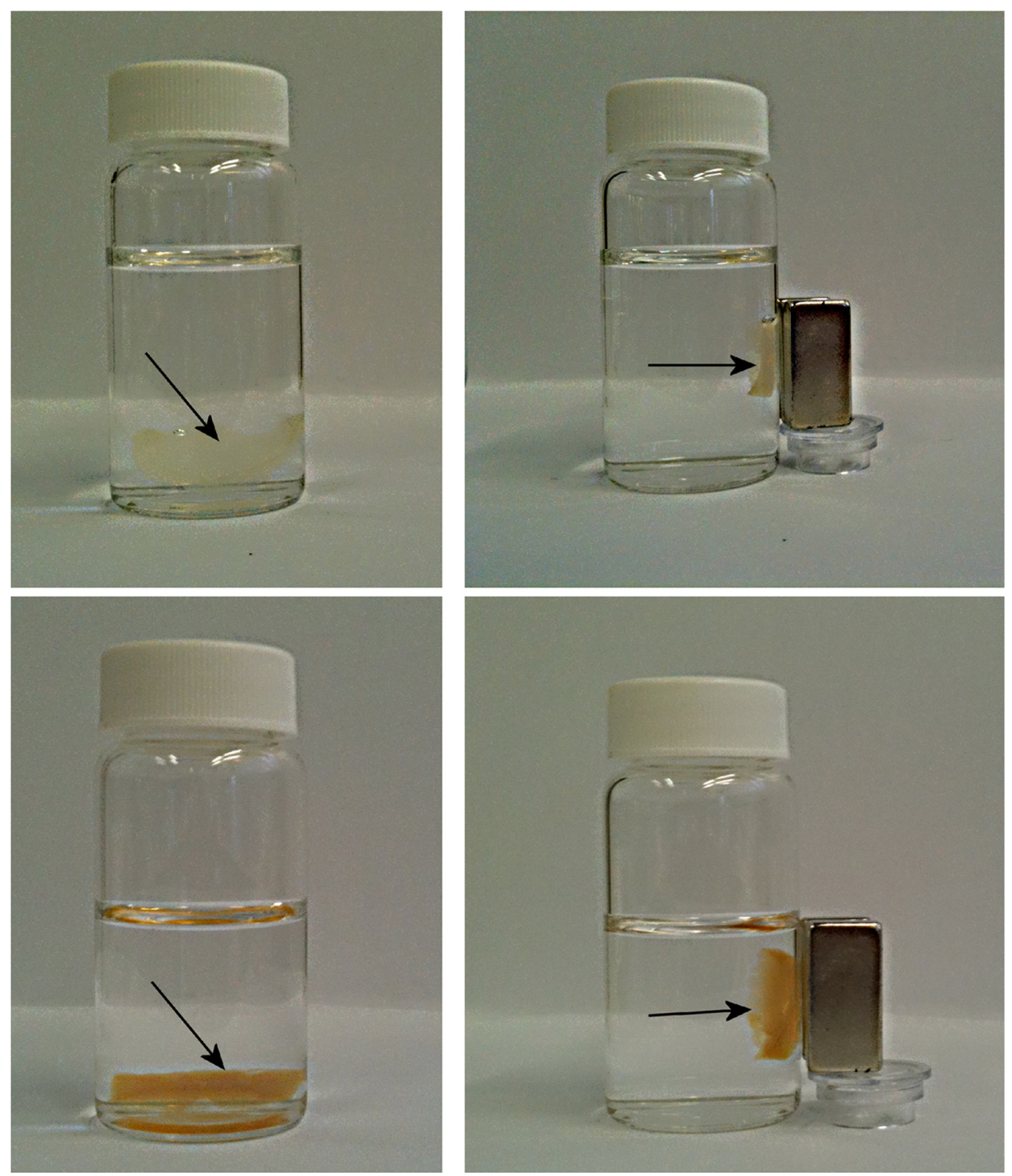

Figure 7 Attraction of the magnetic fibrin hydrogel scaffolds containing $0.15 \%$ (top pictures) or I.5\% (bottom pictures) of the $\gamma$-Fe $\mathrm{O}_{3}$ nanoparticles to a magnet. The top pictures represent the magnetic fibrin hydrogel scaffolds containing the thrombin-conjugated $\gamma$ - $\mathrm{Fe}_{2} \mathrm{O}_{3}$ nanoparticles only. The bottom pictures represent the magnetic fibrin hydrogel scaffolds containing in addition to the thrombin conjugated nanoparticles also the bFGF conjugated $\gamma$-Fe $\mathrm{O}_{3}$ nanoparticles. The arrows point to the magnetic fibrin scaffolds.

Abbreviation: bFGF, basal fibroblast growth factor.

\section{Effect of free bFGF and bFGF conjugated to the $\gamma-\mathrm{Fe}_{2} \mathrm{O}_{3}$ nanoparticles on the growth of NOM cells seeded in the magnetic fibrin hydrogel scaffolds}

Recent experiments have shown that bFGF treatment improves locomotor function via axonal regeneration in transected rat spinal cords, and when combined with neuronal cell grafts, can further amplify axonal extension after injury. ${ }^{25}$ Furthermore, various studies have shown that bFGF promotes neuron survival, spinal cord regeneration and stimulates the proliferation of neuronal precursor cells in cultures. ${ }^{27,30,31}$ Our aim in this part of the study was to compare the effect of the free and the conjugated bFGF nanoparticles on the growth and proliferation of NOM cells seeded in magnetic fibrin hydrogel scaffolds. For this purpose, the cells were seeded in the scaffolds, in the presence or absence of the free or the conjugated-bFGF nanoparticles, either as dissociated cells or attached to the chitosan MCs. These MCs are porous and possess diameters ranging between 100 and $400 \mathrm{~mm}^{52}$ The chitosan has a unique polymeric cationic character that combines with the electronegative groups on the cell surface, which benefits cell adhesion, spreading, and growth. Furthermore, the porous microstructure gives the MCs much greater surface areas for cell cultures and provides efficient nutrition and oxygen supply to the seeded cells. ${ }^{52}$ It has already been proven that the chitosan MCs are a suitable substrate for the adhesion, growth, and differentiation of various cells, 

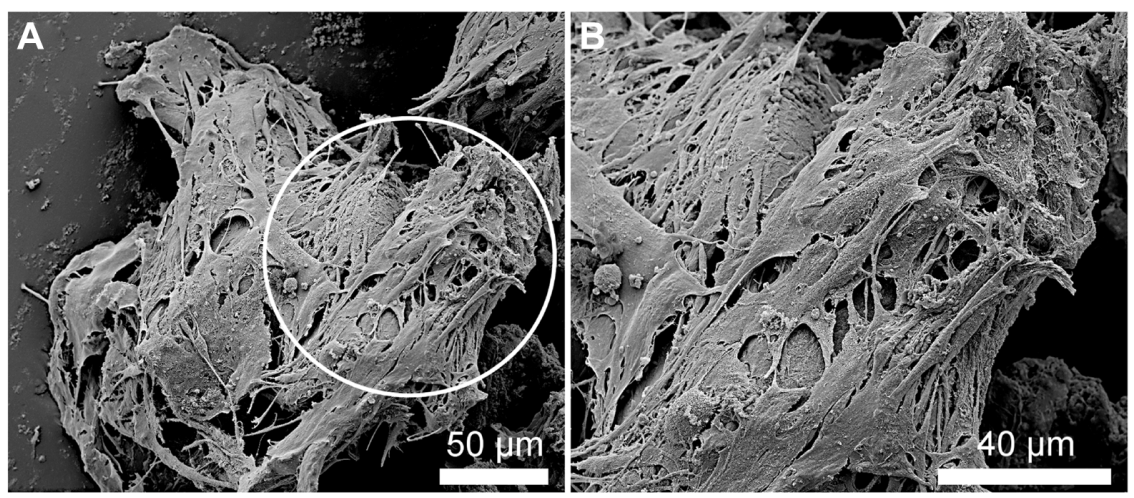

Figure $8 \mathrm{SEM}$ images illustrating the NOM cells attached to the bFGF- $\gamma-\mathrm{Fe}_{2} \mathrm{O}_{3} / \mathrm{MCs}$ aggregates before being transferred to the magnetic fibrin scaffolds. (B) represents higher magnifications of the circulated area shown in (A).

Abbreviations: bFGF, basal fibroblast growth factor; MC, chitosan microcarriers; NOM, nasal olfactory mucosa; SEM, scanning electron microscopy.
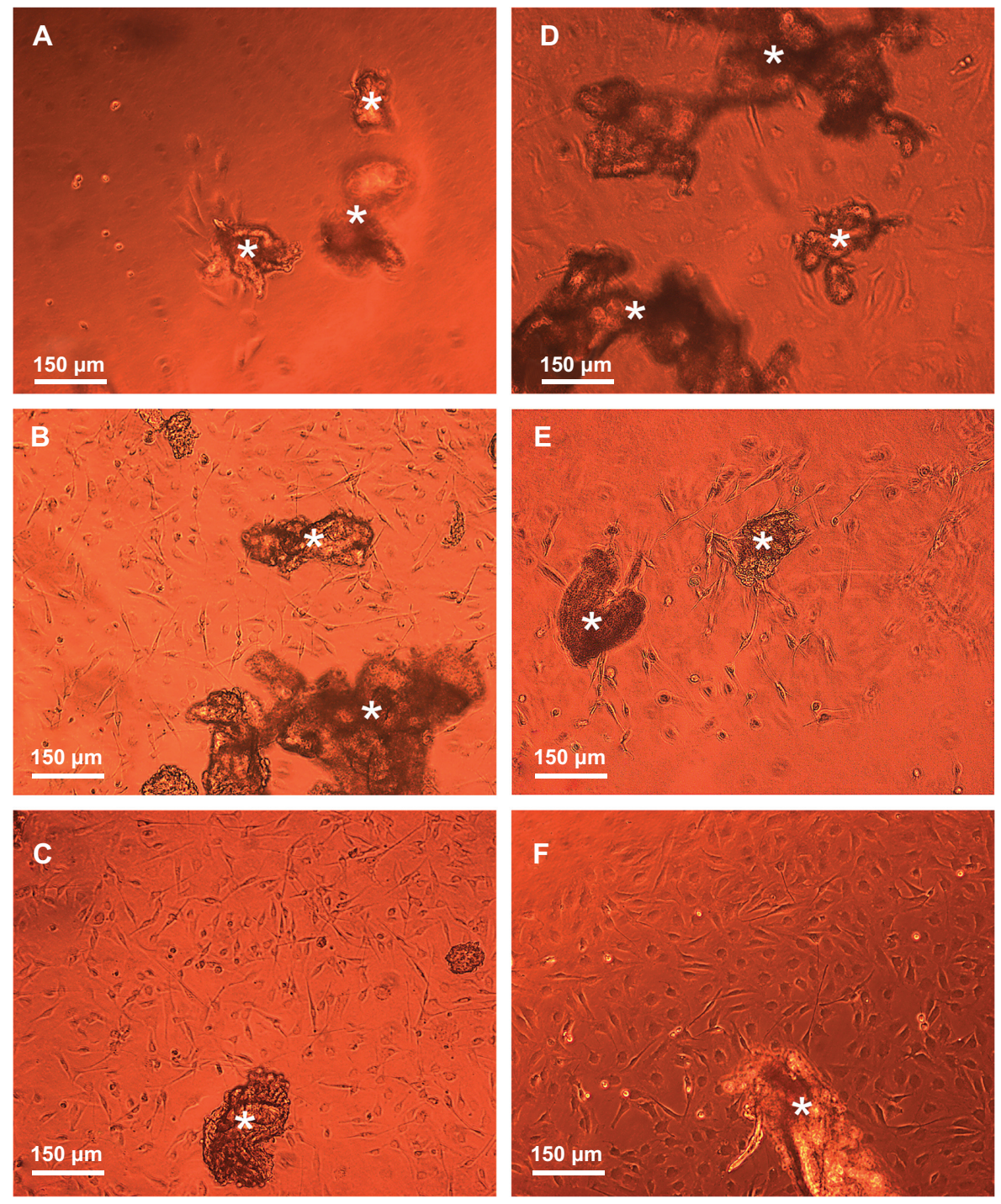

Figure 9 Phase-contrast microscope images illustrating the effect of the free and conjugated bFGF on the migration and growth of the NOM cells from the cells/free or conjugated bFGF/MCs aggregates, 18 days after the cultivation of the cell aggregates in the magnetic fibrin hydrogel scaffolds. (A) exhibits the effect of the naked $\gamma$ - $\mathrm{Fe}_{2} \mathrm{O}_{3}$ nanoparticles (control), (B) the effect of the physically conjugated bFGF nanoparticles, (C) the effect of the covalently conjugated bFGF nanoparticles. The effect of the same concentration of the free factor as that of the conjugated bFGF, and 5 and 10 times higher is illustrated in images (D), (E), and (F), respectively.

Note: The asterisks indicate some of the NOM cells/bFGF- $\gamma-\mathrm{Fe}_{2} \mathrm{O}_{3} / \mathrm{MCs}$ aggregates.

Abbreviations: bFGF, basal fibroblast growth factor; MC, chitosan microcarriers; NOM, nasal olfactory mucosa. 
eg, NOM cells, cerebral neurons, skeletal myoblasts, and cardiac cells. ${ }^{38,53,54}$

Figure 8 illustrates by SEM images the attachment of the $\mathrm{NOM}$ cells to the bFGF- $\gamma-\mathrm{Fe}_{2} \mathrm{O}_{3} / \mathrm{MCs}$. Similar pictures were also observed for the free bFGF/MCs aggregates. The NOM cell/free- or bFGF-conjugated nanoparticle/MCs aggregates were then transferred for proliferation to the magnetic fibrin scaffolds.

Figure 9 demonstrates by typical phase-contrast microscope images the effect of the free and bound-bFGF on the migration of the NOM cells from the MCs aggregates and their growth in the magnetic fibrin hydrogel scaffolds 18 days after their cultivation. Figure $9 \mathrm{~A}$, corresponding to the cell $/ \gamma-\mathrm{Fe}_{2} \mathrm{O}_{3}$ nanoparticle/MCs aggregates, shows MCs aggregates and few cells in the fibrin gel, indicating that the attachment of the naked (nonconjugated) $\gamma-\mathrm{Fe}_{2} \mathrm{O}_{3}$ nanoparticles to the cell/MCs aggregates did not induce significant proliferation and migration of the NOM cells in the magnetic fibrin hydrogel scaffolds. On the contrary, Figure 9B and C show that the attachment of either physical or covalently bFGF-conjugated nanoparticles to the cell/MCs aggregates significantly enhanced the migration and growth of the NOM cells in the magnetic fibrin hydrogel scaffolds. The beneficial effect of the bFGF-conjugated nanoparticles on the NOM cells' growth and migration compared to that of the free factor at the same concentration, and 5 and 10 times higher, is illustrated in Figure 9D, E and F, respectively.
These figures clearly show that the number of the NOM cells migrated from the MCs aggregates to the fibrin scaffolds are substantially higher in the presence of the conjugated bFGF (Figure 9B and C). A similar effect as the covalently bound factor was observed only when the free bFGF was added at a 10 times higher concentration as compared to the bound factor (Figure 9F).

This observation may be due to the fact that the conjugation of bFGF to the nanoparticles increases its stability against inhibitors and proteolytic enzymes present in the culture, and thus prolongs its activity, compared to that of the free factor. A similar stabilization effect was reported previously by us for thrombin, ${ }^{9,42}$ glial cell-derived neurotrophic factors (GDNF), ${ }^{55}$ Factor VII, ${ }^{46}$ and methotrexate ${ }^{56}$ conjugated to the $\gamma-\mathrm{Fe}_{2} \mathrm{O}_{3}$ nanoparticles.

For a quantitative determination of the effect of free/ conjugated $\mathrm{bFGF}$ on the kinetics of the migration of the NOM cells from the MCs aggregates to the magnetic fibrin hydrogel scaffolds, the total number of cells in the fibrin scaffolds was counted using the ImageJ software. Figure 10 illustrates the total number of cells migrated from the cell/ nonconjugated or bFGF-conjugated nanoparticle/MCs aggregates and from the cell/free bFGFs of different concentration/MCs aggregates to the magnetic fibrin scaffolds, 5, 11 , and 18 days after cultivation in the magnetic fibrin scaffolds. As expected, this figure illustrates, for all cultures, an

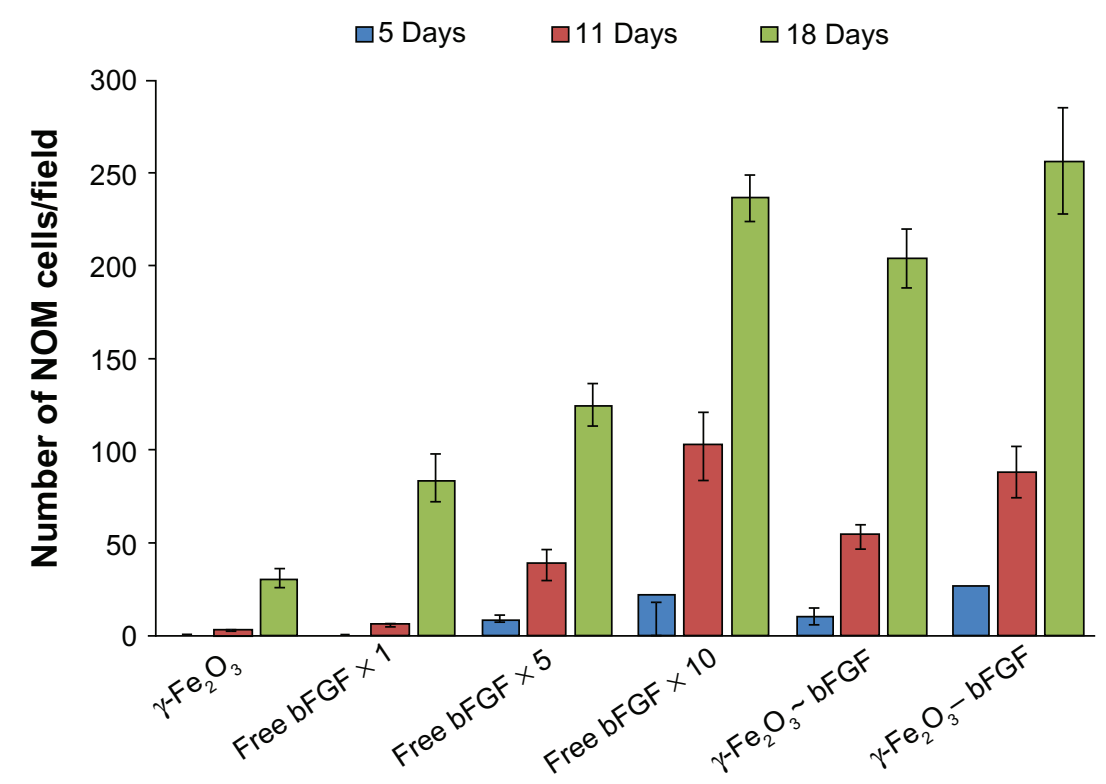

Figure 10 Quantitative analysis of the NOM cells migrated from the cells/nonconjugated or bFGF-conjugated nanoparticles/MCs aggregates and from the cells/different concentrations of the free factor/MCs aggregates (same concentration as the conjugated factor and 5 and 10 times higher), 5, II, and I8 days after the cultivation of the cell aggregates in the magnetic fibrin hydrogel scaffolds. The reported values are an average of measurements performed on at least three randomly nonoverlapping fields of each triplicate tested culture.

Note: and - are symbols for physical and covalent bindings, respectively, of the bFGF to the $\gamma-\mathrm{Fe}_{2} \mathrm{O}_{3}$ nanoparticles.

Abbreviations: bFGF, basal fibroblast growth factor; MC, chitosan microcarriers; NOM, nasal olfactory mucosa. 
increasing number of NOM cells in the fibrin scaffolds as the time of cultivation increased. This figure also illustrates that the migration rate of the NOM cells from the MCs aggregates and their growth in the magnetic fibrin hydrogel scaffolds is according to the following order: $\gamma-\mathrm{Fe}_{2} \mathrm{O}_{3}$-bFGF slightly higher than the $\gamma-\mathrm{Fe}_{2} \mathrm{O}_{3} \sim \mathrm{bFGF}(P>0.05)$, while both are significantly higher than the $\gamma-\mathrm{Fe}_{2} \mathrm{O}_{3}(P<0.05)$. For example, 18 days after cultivation, the number of cells counted in the presence of the $\gamma-\mathrm{Fe}_{2} \mathrm{O}_{3}-\mathrm{bFGF}, \gamma-\mathrm{Fe}_{2} \mathrm{O}_{3} \sim \mathrm{bFGF}$, and $\gamma-\mathrm{Fe}_{2} \mathrm{O}_{3}$ nanoparticles was $257 \pm 29,204 \pm 16$, and $31 \pm 6$ cells/ field, respectively. Figure 10 also exhibits, as expected, the acceleration in the NOM cells' migration and growth as the concentration of the free factor increases. However, the cell migration and growth rate in the presence of the free factor at the same concentration as the conjugated factor (free $\times 1$ ), or even five times higher $(\times 5)$, was significantly lower than that observed for the conjugated factor $(P<0.05)$. Only when the concentration of the free factor was 10 times higher than that of the conjugated factor $(\times 10)$, similar cell migration rates were observed $(P>0.05)$. For example, 18 days after cultivation, the number of cells counted in the presence of the covalently-conjugated $\mathrm{bFGF}$, free $\times 1$, free $\times 5$, and free $\times 10$ was $257 \pm 29,84 \pm 15,124 \pm 11$, and $237 \pm 14$ cells/ field, respectively.

Figure 11 illustrates by typical phase-contrast microscope images the $3 \mathrm{D}$ growth of dissociated NOM cells in the
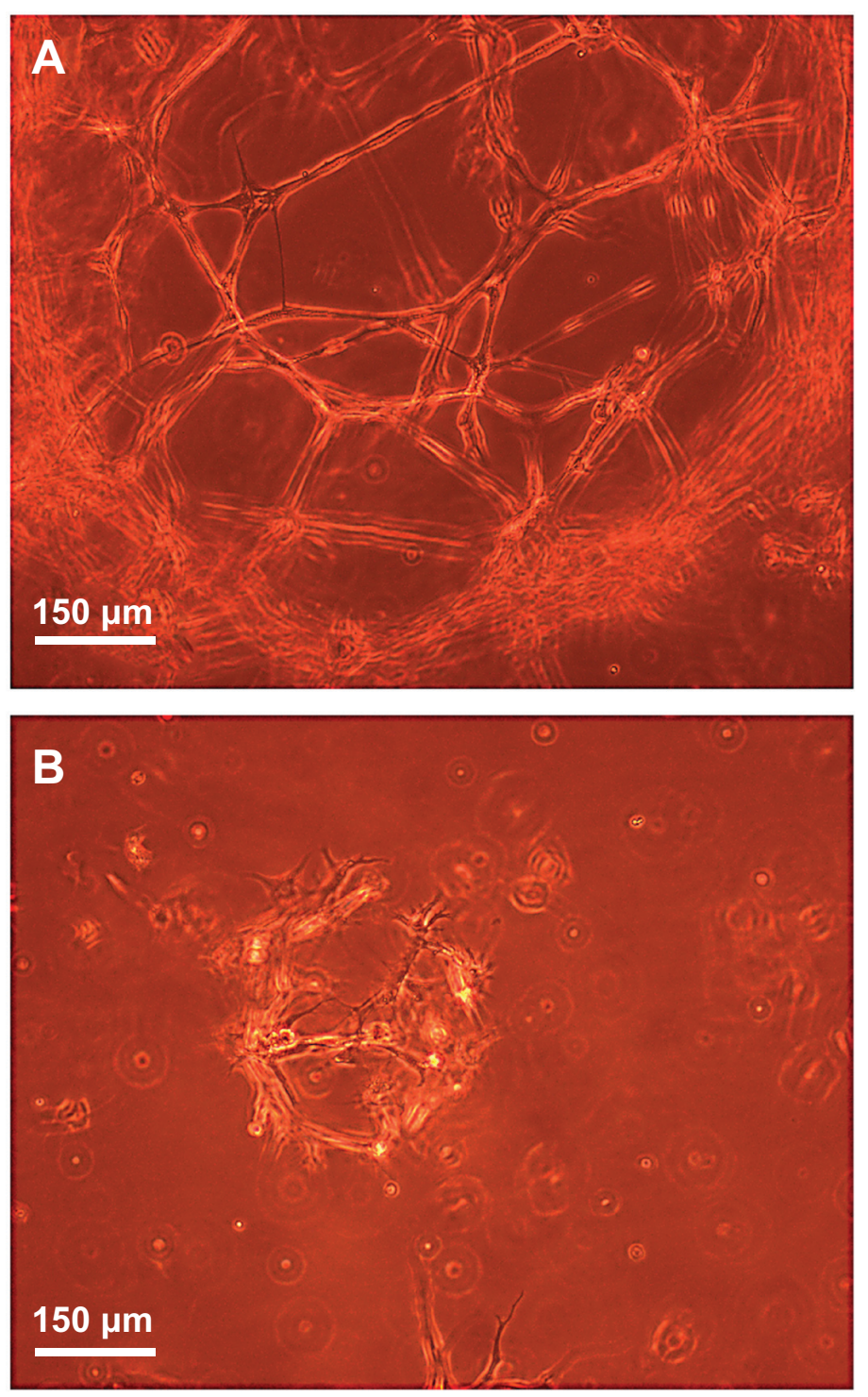

Figure II Phase-contrast microscope images illustrating the three-dimensional growth, proliferation, and differentiation of the NOM cells in the magnetic fibrin hydrogel scaffolds $2 \mathrm{I}$ days postcultivation in the presence (A) and absence (B) of the bFGF- $\gamma$ - $-\mathrm{Fe}_{2} \mathrm{O}_{3}$ nanoparticles.

Abbreviations: bFGF, basal fibroblast growth factor; NOM, nasal olfactory mucosa. 
magnetic fibrin scaffolds 21 days post cultivation in the presence (A) or absence (B) of the covalently bFGF-conjugated $\gamma-\mathrm{Fe}_{2} \mathrm{O}_{3}$ nanoparticles. During this period, the NOM cells in the presence of the bFGF-conjugated nanoparticles formed significantly bigger 3D networks composed mainly of tapered bipolar cells (A) than that observed in the absence of conjugated bFGF (B). These results are in good agreement with a previous publication that demonstrated the positive effect of bFGF on NOM cell proliferation and differentiation into neuron-like cells. ${ }^{28,29}$

\section{Conclusion}

The present manuscript describes the synthesis and characterization of novel magnetic fibrin scaffolds for cell engineering prepared by the interaction of thrombin-conjugated magnetic iron oxide nanoparticles with fibrinogen. In addition, this manuscript shows that the conjugation of bFGF, either covalently or physically, to the $\gamma-\mathrm{Fe}_{2} \mathrm{O}_{3}$ nanoparticles significantly enhances the migration, growth, and differentiation of NOM cells seeded within the fibrin scaffolds compared to the same concentration, or even five times higher, of the free bFGF. In future work we plan to extend these studies to growth factors other than bFGF, eg, GDNF and NGF. In addition, we plan to use the optimal magnetic fibrin scaffolds containing the growing NOM cells and the growth factors conjugated nanoparticles as composite implants for the treatment of spinal cord transacted rats. Since these scaffolds have magnetic properties, we intend to monitor the healing process by MRI.

\section{Acknowledgment/Disclosure}

These studies were partially supported by a Minerva Grant (Microscale and Nanoscale Particles and Films). The authors also wish to thank the following: Mrs. Sara Neuman (NVR Research Ltd, Israel) for her help in this project; Dr Thomas Freier from Medovent GmbH Germany for the supply of chitosan MCs powder; Drs Langzam Yakob, and Judith Grinblat from the Electron Microscopy Unit (Bar-Ilan University, Israel) for their help with the SEM, and HRTEM, to Dror Eliaz (Bar-Ilan University, Israel) for his help in obtaining the immunofluorescence images, and to Dr Igor Grinberg for his help with the graphic work. The authors report no conflicts of interest in this work.

\section{References}

1. Ahmed TAE, Dare EV, Hincke M. Fibrin: a versatile scaffold for tissue engineering applications. Tissue Eng Part B Rev. 2008;14(2): 199-215.

2. Straley KS, Wong Po Foo C, Heilshorn SC. Biomaterial design strategies for the treatment of spinal cord injuries. $J$ Neurotrauma. 2010;27:1-19.
3. Qian L-M, Zhang Z-J, Gong A-H, et al. A novel biosynthetic hybrid scaffold seeded with olfactory ensheathing cells for treatment of spinal cord injuries. Chin Med J. 2009;122(17):2032-2040.

4. Uibo R, Laidmae I, Sawyer ES, Flanagan LA, Georges PC, Winer JP. Soft materials to treat central nervous system injuries: evaluation of the suitability of non-mammalian fibrin gels. Biochim Biophys Acta. 2009;1793(5):924-930.

5. Laurens N, Koolwijk P, de-Maat MPM. Fibrin structure and wound healing. J Thromb Haemost. 2006;4:932-939.

6. Mosesson MW, Siebenlist KR, Meh DA. The structure and biological features of fibrinogen and fibrin. Ann NY Acad Sci. 2001;936:11-30.

7. Jesty J. The kinetics of inhibition of alpha-thrombin in human plasma. J Biol Chem. 1986;261(22):10313-10318.

8. Margel S, Sheichat L, Tennenbaum T, et al; Bar-Ilan University, Israel, assignee. Biological glues based on thrombin conjugated nanoparticles. US patent 7550282, 2009.

9. Ziv O, Lublin-Tennenbaum T, Margel S. Synthesis and characterization of thrombin conjugated $\gamma$-Fe2 $\mathrm{O} 3$ magnetic nanoparticles for hemostasis. Adv Eng Mater. 2009;11(12):B251-B260.

10. Margel S, Gura S; Bar-Ilan University, Israel, assignee. Nucleation and growth of magnetic metal oxide nanoparticles and its use. US patent 139638, 2006.

11. de Vries IJM, Lesterhuis WJ, Barentsz JO, et al. Magnetic resonance tracking of dendritic cells in melanoma patients for monitoring of cellular therapy. Nat Biotechnol. 2005;23(11):1407-1413.

12. Hergt R, Hiergeist R, Hilger I, et al. Maghemite nanoparticles with very high AC-losses for application in RF-magnetic hyperthermia. J Magn Magn Mater. 2004;270(3):345-357.

13. Scherer F, Anton M, Schillinger U, et al. Magnetofection: enhancing and targeting gene delivery by magnetic force in-vitro and in-vivo. Gene Ther. 2002;9(2):101-109.

14. Perlstein B, Ram Z, Daniels D, et al. Convection-enhanced delivery of maghemite nanoparticles: increased efficacy and MRI monitoring. Neuro-Oncol. 2008;10(2):153-161.

15. Mouaziz H, Veyret R, Theretz A, Ginot F, Elaissari A. Aminodextran containing magnetite nanoparticles for molecular biology applications: preparation and evaluation. J Biomed Nanotechnol. 2009;5(2): $172-181$.

16. Medeiros SF, Santos AM, Fessi H, Elaissari A. Stimuli-responsive magnetic particles for biomedical applications. Int J Pharm. 2011;403(1-2):139-161.

17. Ajeesh M, Francis B, Annie J, Harikrishna Varma P. Nano iron oxidehydroxyapatite composite ceramics with enhanced radiopacity. J Mater Sci Mater Med. 2010;21(5):1427-1434.

18. Plank C, Scherer F, Schillinger U, Bergemann C, Anton M. Magnetofection: enhancing and targeting gene delivery with superparamagnetic nanoparticles and magnetic fields. J Liposome Res. 2003;13(1):29-32.

19. Bock N, Riminucci A, Dionigi C, et al. A novel route in bone tissue engineering: magnetic biomimetic scaffolds. Acta Biomater. 2010;6(3):786-796.

20. Hu S-H, Liu T-Y, Tsai C-H, Chen S-Y. Preparation and characterization of magnetic ferroscaffolds for tissue engineering. J Magn Magn Mater. 2007;310(2, Part 3):2871-2873.

21. Sivudu KS, Rhee KY. Preparation and characterization of $\mathrm{pH}$-responsive hydrogel magnetite nanocomposite. Colloids Surf A Physicochem Eng Asp. 2009;349(1-3):29-34.

22. Sasaki T, Iwasaki N, Kohno K, et al. Magnetic nanoparticles for improving cell invasion in tissue engineering. $J$ Biomed Mater Res A. 2008;86A(4):969-978.

23. Shimizu K, Ito A, Honda H. Enhanced cell-seeding into 3D porous scaffolds by use of magnetite nanoparticles. $J$ Biomed Mater Res B Appl Biomater. 2006;77B(2):265-272.

24. Zhong YH, Bellamkonda RV. Biomaterials for the central nervous system. J R Soc Interface. 2008;5(26):957-975.

25. Lu P, Tuszynski MH. Growth factors and combinatorial therapies for CNS regeneration. Exp Neurol. 2008;209(2):313-320. 
26. Bikfalvi A, Klein S, Pintucci G, Rifkin DB. Biological roles of fibroblast growth factor-2. Endocr Rev. 1997;18(1):26-45.

27. Morrison RS, Sharma A, De-Vellis J, Bradshaw RA. Basic fibroblast growth factor supports the survival of cerebral cortical neurons in primary culture. Proc Natl Acad Sci U SA. 1986;83(19):7537-7541.

28. MacDonald KPA, Murrell WG, Bartlett PF, Bushell GR, Mackay-Sim A. FGF2 promotes neuronal differentiation in explant cultures of adult and embryonic mouse olfactory epithelium. J Neurosci Res. 1996;44(1):27-39.

29. Murrell W, Bushell G, Livesey J, et al. Neurogenesis in adult human. NeuroReport. 1996;7:1189-1194.

30. Knusel B, Michel P, Schwaber J, Hefti F. Selective and nonselective stimulation of central cholinergic and dopaminergic development in vitro by nerve growth factor, basic fibroblast growth factor, epidermal growth factor, insulin and the insulin-like growth factors I and II. J Neurosci. 1990;10(2):558-570.

31. Huang Y-C, Huang Y-Y. Tissue engineering for nerve repair. Biomed Eng Appl Basis Comm. 2006;18:100-110.

32. Li S-H, Cai S-X, Liu B, Ma K-W, Wang Z-P, Li X-K. In vitro characteristics of poly(lactic-co-glycolic acid) microspheres incorporating gelatin particles loading basic fibroblast growth factor. Acta Pharmacol Sin. 2006;27(6):754-759.

33. Zhang S, Uludag H. Nanoparticulate systems for growth factor delivery. Pharm Res. 2009;26(7):1561-1580.

34. Willerth SM, Sakiyama-Elbert SE. Cell therapy for spinal cord regeneration. Adv Drug Deliv Rev. 2008;60(2):263-276.

35. Viktorov I, Savchenko E, Ukhova O, Alekseyeva N, Chekhonin V. Multipotent stem and progenitor cells of the ofactory epithelium. Bull Exp Biol Med. 2006;142(4):495-502.

36. Fouad K, Schnell L, Bunge MB, Schwab ME, Liebscher T, Pearse DD. Combining schwann cell bridges and olfactory-ensheathing glia grafts with chondroitinase promotes locomotor recovery after complete transection of the spinal cord. J Neurosci. 2005;25(5):1169-1178.

37. Alexander CL, Fitzgerald UF, Barnett SC. Identification of growth factors that promote long-term proliferation of olfactory ensheathing cells and modulate their antigenic phenotype. Glia. 2002;37(4):349-364.

38. Rochkind S, Shahar A, Fliss D, et al. Development of a tissue-engineered composite implant for treating traumatic paraplegia in rats. Eur Spine J. 2006;15(2):234-245.

39. Mackay-Sim A, St John JA. Olfactory ensheathing cells from the nose: Clinical application in human spinal cord injuries. Exp Neurol. 2011;229(1):174-180.

40. Ziv O, Avtalion RR, Margel S. Immunogenicity of bioactive magnetic nanoparticles: natural and acquired antibodies. J Biomed Mater Res A. 2008;85(4):1011-1021.

41. Svoboda J. Magnetic Techniques for The Treatment of Materials. London: Kluwer Academic Publishers; 2004.

42. Ziv-Polat O, Topaz M, Brosh T, Margel S. Enhancement of incisional wound healing by thrombin conjugated iron oxide nanoparticles. Biomaterials. 2010;31(4):741-747.
43. Bradford M. A rapid and sensitive method for the quantitation of microgram quantities of protein utilizing the principle of protein-dye binding. Anal Biochem 1976;72:248.

44. Margel S, Lublin-Tennenbaum T, Gura S, et al. Synthesis and characterization of nano- and micron-sized iron oxid and iron particles for biomedical applications. In: Zborowski M, Chalmers JJ, editors. Book series: Laboratory Techniques in Biochemistry and Molecular Biology, Volume 32: Magnetic Cell Separation. Amsterdam: Elsevier; 2008:119-157.

45. Peters TJ. All About Albumin: Biochemistry, Genetics and Medical. San Diego, CA: Academic Press Inc; 1996.

46. Shafir G, Galperin A, Margel S. Synthesis and characterization of recombinant factor VIIa-conjugated magnetic iron oxide nanoparticles for hemophilia treatment. J Biomed Mater Res A. 2009;91A(4):1056-1064.

47. Rowe SL, Lee S, Stegemann JP. Influence of thrombin concentration on the mechanical and morphological properties of cell-seeded fibrin hydrogels. Acta Biomater. 2007;3(1):59-67.

48. Ferry JD, Morrison PR. Preparation and properties of serum and plasma proteins VIII. The conversion of human fibrinogen to fibrin under various conditions. J Amer Chem Sot. 1947;69:388-400.

49. Blomback B, Carlsson K, Fatah K, Hessel B, Procyk R. Fibrin in human plasma: Gel architectures governed by rate and nature of fibrinogen activation. Thromb Res. 1994;75(5):521-538.

50. Willerth SM,Arendas KJ, Gottlieb DI, Sakiyama-Elbert SE. Optimization of fibrin scaffolds for differentiation of murine embryonic stem cells into neural lineage cells. Biomaterials. 2006;27(36):5990-6003.

51. Bensaid W, Triffitt JT, Blanchat C, Oudina K, Sedel L, Petite H. A biodegradable fibrin scaffold for mesenchymal stem cell transplantation. Biomaterials. 2003;24(14):2497-2502.

52. Martin Y, Eldardiri M, Lawrence-Watt DJ, Sharpe JR. Microcarriers and their potential in tissue regeneration. Tissue Eng Part B Rev. 2011;17(1):71-80.

53. Shahar A, Reuveny S. Nerve and muscle cells on microcarriers in culture. Vertrebrate Cell Culture I. Vol 34: Springer Berlin/Heidelberg; 1987:33-55.

54. Shahar A, Reuveny S, DavidY, Budu C, Shainberg A. Cerebral neurons, skeletal myoblasts, and cardiac muscle cells cultured on macroporous beads. Biotechnol Bioeng. 1994;43(8):826-831.

55. Green-Sadan T, Kuttner Y, Lublin-Tennenbaum T, et al. Glial cell line-derived neurotrophic factor-conjugated nanoparticles suppress acquisition of cocaine self-administration in rats. Exp Neurol. 2005;194(1):97-105.

56. Corem-Salkmon E, Ram Z, Daniels D, et al. Convection-enhanced delivery of methotrexate-loaded maghemite nanoparticles. Int $J$ Nanomedicine. 2011;6(1):1595-1602.
International Journal of Nanomedicine

\section{Publish your work in this journal}

The International Journal of Nanomedicine is an international, peerreviewed journal focusing on the application of nanotechnology in diagnostics, therapeutics, and drug delivery systems throughout the biomedical field. This journal is indexed on PubMed Central, MedLine, CAS, SciSearch ${ }^{\circledR}$, Current Contents ${ }^{\circledR} /$ Clinical Medicine,

\section{Dovepress}

Journal Citation Reports/Science Edition, EMBase, Scopus and the Elsevier Bibliographic databases. The manuscript management system is completely online and includes a very quick and fair peer-review system, which is all easy to use. Visit http://www.dovepress.com/ testimonials.php to read real quotes from published authors. 